\title{
1 Parasitism, personality and cognition in fish
}

3 Barber, I. ${ }^{1 *}$, Mora, A.B. ${ }^{2}$, Payne, E.M. ${ }^{2}$, Weinersmith, K.L. ${ }^{3}$ \& Sih, A. ${ }^{2}$

4

5 1. Department of Neuroscience, Psychology \& Behaviour, College of Medicine,

6 Biological Sciences and Psychology, University of Leicester, Leicester LE1 7RH, UK

7 2. Department of Environmental Science and Policy, University of California Davis,

8 Davis, California, USA

$9 \quad{ }^{3 .}$ BioSciences Department, Rice University, Houston, Texas, USA

12 * Corresponding author: Iain Barber, Department of Neuroscience, Psychology \&

13 Behaviour, Adrian Building, College of Medicine, Biological Sciences and

14 Psychology, University of Leicester, Leicester LE1 7RH, UK, Email: $\underline{\text { ib50@le.ac.uk, }}$

15 Telephone: 0116252 3462, Fax: 01162523330

16

Running title: Personality and parasites in fish

20 Key words: manipulation; disease; infection; syndromes; personality; cognition. 


\section{Abstract}

It is well established that parasites can have profound effects on the behaviour of host organisms, and that individual differences in behaviour can influence susceptibility to parasite infections. Recently, two major themes of research have developed. First, there has been a growing interest in the proximate, mechanistic processes underpinning parasite-associated behaviour change, and the interactive roles of the neuro-, immune, and other physiological systems in determining relationships between behaviour and infection susceptibility. Secondly, as the study of behaviour has shifted away from one-off measurements of single behaviours and towards a behavioural syndromes / personality framework, research is starting to focus on the consequences of parasite infection for temporal and contextual consistency of behaviour, and on the implications of different personality types for infection susceptibility. In addition, there is increasing interest in the potential for relationships between cognition and personality to also have implications for host-parasite interactions. As models well-suited to both the laboratory study of behaviour and experimental parasitology, teleost fish have been used as hosts in many of these studies. In this review we provide a broad overview of the range of mechanisms that potentially generate links between fish behaviour, personality, and parasitism, and illustrate these using examples drawn from the recent literature. In addition, we examine the potential interactions between cognition, personality and parasitism, and identify questions that may be usefully investigated with fish models. 


\section{Introduction: Behaviour, personality and parasite infections in fish}

Interest in the relationships between host behaviour and parasite infections has persisted for decades (Moore 2002; Barnard and Behnke 1990; Sukhdeo 1994; Moore 2013, 2012), and has intensified over recent years as new experimental approaches and tools have become available to address tantalizing questions, such as how parasites manipulate the behaviour of their hosts through neuromodulation (Adamo 2013; Adamo and Webster 2013; Thomas, Adamo, and Moore 2005; Hébert and Aubin-Horth 2014). Importantly, the behaviour of animals and their parasite infections may be linked at a range of phenotypic, ecological and evolutionary levels, and through a wide range of mechanisms, including those by which pre-existing behavioural variation influences infection susceptibility (Hart 1990, 1997). Identifying the drivers of correlations between behaviour and infection, disentangling cause from effect, as well as identifying the neurophysiological mechanisms that underpin infection-associated behavioural variation among hosts (Demas, Adamo, and French 2011; Beckage 1997; McCusker and Kelley 2013; Adamo 2012), remain centrally important topics in this rapidly developing field (Poulin 2010; Poulin 1994).

Teleost fish are frequently used in studies investigating these relationships, as they are behaviourally well-characterized (Pitcher 1993; Godin 1999; Reebs 2001; Magnhagen et al. 2008) and are well-studied subjects in both lab and field parasitology (Buchmann 2007; Woo and Buchmann 2011). Furthermore, various small-bodied fish species - including sticklebacks, killifish, zebrafish, and guppies - are ideally suited to study under controlled laboratory conditions, and have been developed as excellent models for behaviour and / or experimental parasitology (Scott 1985; Lafferty and Morris 1996; Barber 2013), facilitating their use in studies aimed at understanding linking mechanisms. As a consequence, a significant body of work has emerged 
examining the interactions between parasite infections and patterns of fish behaviour. Another benefit is that steroid hormones can be measured repeatedly and noninvasively, as they leak across the gills (Ellis, Sanders, and Scott 2013; Scott et al. 2008), meaning that relationships between behaviour, infection and (for example) cortisol can be studied experimentally. The recent development of fish as models for the experimental study of animal cognition (Brown, Laland, and Krause 2011), personality and behavioural syndromes (Conrad et al. 2011; Toms, Echevarria, and Jouandot 2010), means fish are ideally placed to give further insights into the mechanisms underlying relationships between individual differences in behaviour and parasitism.

Our aim in this review is to give a broad overview of the range of mechanisms that potentially generate links between fish behaviour and parasitism, and illustrate these using examples drawn from the recent literature. In addition, we examine the potential mechanisms linking cognition, personality and parasitism that may be usefully investigated using fish.

\subsection{Infection-associated variation in fish behaviour: cause, effect or corollary?}

While it is well established that patterns of behaviour among individual fish frequently co-vary with their level of infection with parasites (Barber, Hoare, and Krause 2000), very often these associations are based on correlational data, arising from behavioural studies carried out on wild-caught fish that vary naturally in infection intensity. Whilst these types of studies can generate interest and stimulate the development of testable hypotheses about underpinning mechanisms, they may give only weak insights into the likely ecological consequences or evolutionary basis 
91 of relationships. There are a number of reasons to be cautious when interpreting such correlations. First, as well as varying in the load of the focal parasite, wild-caught organisms often harbor mixed infections with a variety of parasite and pathogen species, making it difficult to attribute behavioural differences to any particular infecting agent (e.g. Hammond-Tooke, Nakagawa, and Poulin 2012; Petney and to an increased (or decreased) probability of infection by another (e.g. Seppälä et al. 2009), a mechanism that can contribute to the generation of diverse parasite communities among individual hosts (Rynkiewicz, Pedersen, and Fenton 2015). Second, parasites are acquired through a wide diversity of routes, many of which are ecological (including those acquired through feeding or social contact, or when inhabiting specific habitats), so pre-existing behavioural differences among wildsampled fish may have influenced levels of exposure to parasites, potentially driving their likelihood of reliable performance in experimental behavioural trials.

Recognizing these difficulties associated with using naturally infected fish to test hypotheses about the ecological consequences, evolutionary implications or mechanistic bases of infection-associated behavioural variation, researchers have

111 adopted a range of approaches to link behavioural differences among individuals more clearly to parasite infections. Experimental infections of lab bred fish that are

113 free from co-infections - and can be standardized in terms of their genetic

114 background, age, nutritional background and growth history - have been used to 115 demonstrate causal links between infection and behaviour change in some cases. 
More recently, there has been a shift toward using post-genomic tools to examine the

117 effects of parasites on host behavior and underlying physiology, and this appears to

118 offer a promising approach in the search for underpinning mechanisms (Hughes 2013;

119 Biron and Loxdale 2013; Hébert and Aubin-Horth 2014).

\subsection{Personality studies versus 'simple' behavioural studies}

122 Over the past decade the fields of animal behaviour and behavioural ecology have experienced a paradigm shift in the way in which behaviour is studied, quantified and considered, with a move away from examining individual behaviours in isolation and toward investigating behaviour within an 'animal personality’ or 'behavioural syndromes’ framework (Sih and Bell 2008; Sih, Bell, and Johnson 2004; Reale et al. 2007). The major conceptual difference between these two approaches is that while 'simple' behavioural studies tend to examine single dimensions (antipredator behaviour, social behaviour, aggression, etc.) at one point in time, personality studies typically attempt to consider longer-term consistency of behavioural differences

131 among individuals and the extent to which this generates a predictable syndrome of

132 behaviours across contexts. As a consequence, the concept of animal personality

133 incorporates notions of temporal consistency in behaviour, and of the cross-contextual 134 nature of individual behavioural differences, both of which have far-reaching 135 implications for interactions with parasites (Barber and Dingemanse 2010; Kortet, 136 Hedrick, and Vainikka 2010; Poulin 2010; Poulin 2013).

137 An example may serve to outline the distinction between the simple 'behavioural' and

138 the 'personality' paradigms, in the context of the current review. Hungry fish may need to investigate risky foraging environments and as a consequence expose 
themselves to infective parasites that may be prevalent in such environments. A study in which we hold some fish without food for a period of time and then study their propensity to explore a risky foraging habitat would give insight into how a particular behaviour (in this case exploration) might affect parasite exposure. Similar approaches could be taken to investigate the risk of promiscuous behaviour on susceptibility to sexually-transmitted infections (STIs), or shoal membership on acquiring socially-transmitted parasites. However, while documenting how specific behaviours affect parasite exposure provides an important first step, this might be less insightful at an ecological or evolutionary level, since most (or even all) fish will be hungry, reproductively active or sociable at some points in their lives, and so spend a proportion of their time exposed to elevated infection risk. However, if some individual fish are consistently more likely to forage in risky habitat, engage in sexual activity or join shoals - as a consequence of 'personality', underpinned by physiological or genetic differences - then this would be expected to have a far greater ecological or evolutionary relevance, not least in terms of the distribution of parasites among and within host populations. Furthermore, if behavioural differences between individuals are consistent over time, this might also promote behavioural syndromes - relationships between contextually different behaviours within individual fish (Conrad et al. 2011; Sih, Bell, and Johnson 2004) - that may also have implications for interactions with parasites (Barber and Dingemanse 2010; Kortet, Hedrick, and Vainikka 2010; Poulin 2013).

The previous example exemplifies the notion that behavior and personality affect an individual's probability of exposure, but other stages exist in the host-parasite interaction (Figure 1). Indeed, behaviour and personality can also connect - via various physiological mechanisms - with the probability of infection given a 
particular level of exposure (Hawley et al. 2011; McCusker and Kelley 2013). Infected hosts often display a distinct phenotype from uninfected conspecifics, a phenotype that of course includes behaviour and personality (Adamo 2012; Adamo 2013; Adamo and Webster 2013). Thus, as both individual behaviours and personality can affect the host-parasite interaction, a consideration of both types of studies is appropriate, and included in this review relevant to the different stages of the interaction.

\section{[FIGURE 1 HERE]}

\section{Behaviour, personality and infection susceptibility}

There is growing evidence, from a wide range of taxa including fish, that pre-existing differences in behaviour can influence the interactions of host organisms with parasites, potentially driving correlations between host behaviour and infection (Koprivnikar, Gibson, and Redfern 2012; Stumbo et al. 2012; James et al. 2008; Wisenden, Goater, and James 2009; Dizney and Dearing 2016; Aalvik et al. 2015; Boyer et al. 2010). Most intuitively, a correlation may arise if behaviour alters the likelihood of exposure (Daly and Johnson 2011; Dizney and Dearing 2013). However, other mechanisms may also play a role. Individual immuno-physiological differences often have implications for both behaviour or personality and the probability of an encountered infective parasite establishing (Kittilsen et al. 2012; Øverli, Kotzian, and Winberg 2002; Øverli et al. 2002; Øverli, Winberg, and Pottinger 2005; Hawley et al. 2011). Furthermore, pre-existing behaviour / personality differences may have implications for infections post-establishment if, for example, individuals with different personalities are more (or less) likely to engage in infection-reduction 
behaviours (Zylberberg, Klasing, and Hahn 2014; Zylberberg, Klasing, and Hahn 2013), or provide environments that are differently suitable for parasite growth, development or proliferation. Here we consider each of these mechanisms separately, detailing examples from fish where they exist, highlighting knowledge gaps and identifying areas for future study.

\subsection{Probability of exposure influenced by behaviour or personality}

Parasites exhibit a broad range of life cycles and transmission strategies, and fish become infected through many different routes. Consequently, whether - and the extent to which - particular behaviours are likely to influence parasite exposure will depend on the nature of transmission of parasite species.

Most studies examining the impact of behaviour on parasitism have focused on social behaviour. Associating with conspecifics could potentially increase or decrease exposure to parasites, depending on the specific nature of parasite transmission (Rifkin, Nunn, and Garamszegi 2012; Patterson and Ruckstuhl 2013; Côté and Poulin 1995). For directly-transmitted parasites that rely on close inter-individual distances for transfer between hosts, and which are often capable of rapid proliferation on the skin of the host, increased tendency to aggregate (i.e. join groups) or shoal more tightly is likely to lead to enhanced rates of transmission. For example, shoaling behaviour drives higher rates of monogenean (Gyrodactylus spp.) transmission in guppies Poecilia reticulata. Among shoals of fish held under lab conditions, and 'seeded' with controlled numbers of infected fish, parasite transmission was increased when shoal members showed more frequent and more prolonged contact (Richards, van Oosterhout, and Cable 2010). In that study, females shoaled more than males and 
213 as a result had a four-fold increased risk of becoming parasitized; however, in a

214 subsequent study males exhibited greater numbers of intra-specific interactions and

215 had correspondingly high transmission rates (Richards, van Oosterhout, and Cable

216 2012). It therefore appears that shoaling per se, rather than any inherent differences

217 between the sexes, is responsible for increased transmission rates in this system.

218 Consistent with this, Richards (2010) found that shy individuals, which formed tighter

219 shoals, showed both higher levels of infection and greater increases in infection load

220 (Richards 2010); however, whether increased susceptibility arose solely from

221 increased transmission opportunity, or was influenced by lower resistance of shy fish

222 to infections (see section 2.2) is unclear.

223 In contrast, for parasite transmission strategies that rely on individual, free-swimming 224 infective stages targeting individual hosts - i.e. host-seeking behaviour similar to the 225 attack strategies of predators - aggregated fish may benefit from ‘dilution’ or

226 'swamping' effects akin to those that provide antipredator benefits (Ims 1990; Pitcher 227 and Parrish 1993), with the per capita risk of infection being reduced in larger groups 228 (Mooring and Hart 1992; Poulin and Fitzgerald 1989; Côté and Gross 1993).

229 However, more complex relationships have also been demonstrated; for example, 230 among coral reef fish, fish in intermediate-sized shoals appear to gain the most 231 protection against ectoparasite infections (Sasal 2003).

232 Shoal members may also benefit from an increased ability to detect infective 233 parasites, and can adopt other group behaviours that can reduce the likelihood of 234 infection. Mikheev et al. (2013) found that rainbow trout Oncorhynchus mykiss held 235 in groups of five were better able to detect (and avoid) compartments of an 236 experimental tank harboring snails shedding infective cercariae of the 237 trematode Diplostomum pseudospathaceum than fish housed individually. Fathead 
minnows Pimephales promelas held in groups were better protected against infective trematode cercariae than singly-held fish; in the presence of parasites groups became more cohesive and compact, with antiparasite benefits being greatest among individuals occupying central positions (Stumbo et al. 2012).

242 Few studies have examined the implications of variation in non-social behaviors for 243 infection exposure in fish, yet variation in any of the major axes of personality might 244 reasonably be expected to be associated with altered susceptibility to infection by 245 parasites. For example, individual variation in aggression might be expected to 246 influence damage to skin and fins arising from encounters, rendering more aggressive 247 individuals that engage more frequently in fights more susceptible to acquiring 248 secondary infections by water-borne pathogens (e.g. in caged salmonids: Turnbull et al. 1998; Abbott and Dill 1985). Variation in exploration tendency or general activity levels might also be important; more active or more exploratory individuals may be exposed to a greater number or a greater diversity of parasites if they have greater

252 home range size, or sample a greater diversity of habitat types. However, while 253 correlations between boldness and parasite loads have been reported among wild caught fish (Wilson et al. 1993), we are not aware of any studies that have examined these links experimentally. While such relationships may appear intuitive, studies of wild-sampled mammal populations have not supported the hypothesis (Bordes et al.

257 2009; Nunn et al. 2003; Ezenwa et al. 2006). These studies are typically

258 compromised, however, by potentially important confounding factors, such as 259 relationships between individual quality (including immunocompetence) and home 260 range size. Fish may offer ideal subjects for future experimental tests of these 261 hypotheses. Individual differences in sexual behaviour might also predispose certain 262 individuals to sexually transmitted infections. Interspecific differences in promiscuity 
can be substantial even among closely related species (Fitzpatrick et al. 2009), and in species that exhibit active mate choice, individuals vary in the extent to which they sample mates (Lindström and Lehtonen 2013). While we know of no studies that have examined how individual differences in promiscuity influence parasite exposure in

267 fish, more promiscuous honey bees (Apis mellifera) have a higher risk of infection with Nosema microsporidians (Roberts et al. 2015). Such mechanisms have potential implications for the transmission of ectoparasites among externally-fertilizing fish, and microparasites of internal fertilizers

271 Inter-individual variation in energy metabolism and 'pace of life' has been suggested

272 as a possible explanation for maintenance of personality differences within and

273 between populations (Careau et al. 2008; Reale et al. 2010). Variation in the basal or resting metabolic rate, which is expected to co-vary with personality in fish (but see

275 White, Kells, and Wilson 2016) may also have implications for the likelihood of 276 parasite encounter. For example, fish with higher metabolic rates may emit stronger 277 odour plumes that can be tracked by free-swimming parasites such as ectoparasitic 278 lice or trematode cercariae (Mikheev, Pasternak, and Valtonen 2004), or have higher opercular beat frequencies, which increases the number of infective stages that are 280 'filtered through the gills (Mikheev et al. 2014).

\subsection{Influence of physiological correlates of personality on the probability of}

283 infection following exposure

284 Another mechanism that could generate links between pre-existing behavioural

285 variation and parasite infection is the underpinning role of the neuroendocrine and immuno-physiological systems in behaviour and immune functioning (Winberg et al. 
1997; Dufour et al. 2010; Øverli, Pottinger, et al. 2001). Individual differences in these systems have the potential to co-affect both individual personality and the probability of infection given a fixed level of exposure. For example, cortisol - the key hormone in the stress response of fish - has significant effects for energy metabolism, the innate immune response and the behaviour (including the aggression and locomotor activity) of rainbow trout (Øverli, Kotzian, and Winberg 2002; Cortés et al. 2013). As a consequence, trout selected for stress responsiveness develop highly divergent behavioural and neuroendocrine phenotypes (Øverli et al. 2002; Øverli, Winberg, and Pottinger 2005), with likely implications for their interactions with infective parasites. Cortisol, and the expression of a number of genes involved in the stress response, are also correlated with personality among wild-caught sticklebacks (Aubin-Horth, Deschênes, and Cloutier 2012). In salmonids, cortisol is also associated with skin melanin pigmentation (Kittilsen et al. 2009), which itself is known to be associated with variability to infection with ectoparasitic sea lice Lepeophtheirus salmonis. Taken together these studies suggest an underlying role of steroid hormones such as cortisol in determining phenotypic syndromes spanning behaviour, pigmentation, neuroendocrine and immune function in fish (Kittilsen et al. 2012).

\subsection{Variation in host infection phenotype, dependent on personality}

Infection phenotype is a concept that combines information on both the intensity or severity of infection with the host responses to infection - including its behaviour,

308 physiology and immune function. Infection phenotype can therefore be considered as the way in which a particular infection manifests itself in a specific host individual, and presents as a disease. We propose that pre-existing variation in behaviour or

311 personality might alter the infection phenotype of individuals though two non- 
exclusive mechanisms.

313 First, individual variation in personality might alter the probability that infected fish

314 exhibit infection reduction behaviours. Many animals have evolved specific

315 behaviours - ranging in complexity from prey choice and grooming through to self-

316 medication - to avoid parasites, or reduce their levels of infection once parasitized

317 (Hart 1990, 1997). Fish engage in a wide range of such behaviours, including simple

318 behaviours such as flashing and jumping that dislodge ectoparasites, to more complex

319 social behaviours, including highly ritualized interactions with cleaner fish.

320 Personality may influence the likelihood of individuals engaging successfully in these

321 types of infection-limiting behaviours, especially in the case of cleaner-client

322 interactions, in which the behavior of client fish at cleaning stations can significantly

323 impact the likelihood of being cleaned (Côté, Arnal, and Reynolds 1998). However,

324 while it is known that variation in the personality of cleaner wrasse Labroides

325 dimidiatus in a non-cleaning context carries over to their cleaning behaviour (Wilson

326 et al. 2014), we are not aware of any studies linking individual personality among

327 client fish to the likelihood of seeking out cleaners or being cleaned. Given the level

328 of interest in cleaner-client systems in fish, we suggest this might prove a fruitful

329 avenue for future research.

330 Second, physiological mechanisms that underpin behavioural variation might

331 influence the progression of infection, following establishment. For example, if

332 personality variation is linked to energy metabolism (Careau et al. 2008), immunity

333 (Koolhaas 2008) or other component of 'pace-of-life' (Reale et al. 2010), or if it

334 affects competitive foraging ability, then this is likely to have implications for food

335 intake, or otherwise affect the availability of nutrients to growing or developing

336 parasites. While no studies have directly tested this hypothesis in fish, it is known that 
parasite performance can be related to patterns of host growth and alimentation. For example, host growth rate co-varies with parasite growth in sticklebacks infected with Schistocephalus solidus (Barber 2005), suggesting that any physiological factors underpinning behavioural differences that affect host energetics are also likely to affect parasite performance in infected fish. In lab trials, sticklebacks that consistently exhibited more 'bold' behavior in experimental screenings in a non-foraging context also exhibited increased voluntary food intake under a no-competition scenario (Jolles, Manica, and Boogert 2016), supporting predictions of the 'pace-of-life' theory, and suggesting that pre-existing personality differences are likely to influence certain infection phenotypes.

\subsection{Do population differences in personality relate to the threat of infection?}

A number of influential studies have examined how inter-population variation in predation threat impact the personality of fish populations, demonstrating that fish populations facing high predation risk typically exhibit stronger behavioural syndromes than those from lower predation risk regimes (Dingemanse et al. 2007; Bell 2005). Since populations of host organisms can also vary consistently in the level of threat they face from parasites (Poulin and Morand 1999; Wilson 1998) any link between individual personality and infection risk could also lead to the evolution of populations that differ in personality, or in the strength or direction of behavioural syndromes. Such mechanisms, for example, have been implicated as causal factors underpinning observed correlations between parasite infection risk and average personality in different human societies (Fincher and Thornhill 2014).Furthermore, as discussed in 2.3 above, if infections have dramatically different consequences for the reproductive success or survival of hosts with divergent pre-existing personality, they 
could select for differential personality types, or different behavioural syndromes, among populations that vary in the level or type of parasite exposure they normally experience (Barber and Dingemanse 2010).

Experimental studies examining such relationships in fish are now beginning to emerge. Kortet et al. (2015) compared personalities in two European minnow Phoxinus phoxinus populations that differed in both their intrinsic risk of parasite infection and in their predation risk, and identified population-level differences in personality; however, since infection and predation risk were confounded in these populations, it was not possible to test the hypothesis that parasitism could drive selection of personality. As a first step to determining the potential for parasites to shape the evolution of personality in host populations, experimental studies are needed that quantify the parasite susceptibility and infection phenotypes of fish that vary in their pre-exposure personality. Most recently, Jacquin et al. (2016) quantified behavioural variation among wild-caught and lab-bred guppy Poecilia reticulata populations that varied in both predation and parasitism risk, to determine the importance of each factor for behavioural phenotypes. Both factors were associated with behavioural variation between the populations, but while behavioural variation associated with predation differences had a strong genetic component and was retained in lab-bred fish, this was not the case for differences associated with differences in infection risk. The study suggests that population differences in behaviour associated with parasitism are more likely to reflect behavioural plasticity, and that parasites have a more transitory effect on behaviour than predators.

\section{Parasite infections that change host behaviour}


In contrast to the relative lack of studies that have investigated the consequences of individual differences in behaviour and personality for exposure and susceptibility to infection, the post-infection behaviour of fish has been extensively studied. Providing an encyclopedic coverage of all examples of infection-associated behavioural variation in fish is beyond the scope of this review, so we refer the reader to the selected examples presented in Table 1 (chosen to illustrate the diversity of behaviours, host and parasite taxa that have been investigated), and also to published reviews that focus on fish host-parasite systems (Barber, Hoare, and Krause 2000; Barber and Rushbrook 2008; Barber and Wright 2006).

In this section we instead focus on two key aspects of parasite-mediated behaviour change that have been advanced by studies employing fish host-parasite models. First, we look at how experimental fish-parasite systems are informing our understanding of the neurophysiological mechanisms underpinning parasite mediated behaviour change. Second, we examine how model fish-parasite systems are being used to investigate parasite-mediated host behaviour change within the animal personality and behavioural syndromes frameworks.

\subsection{Neurophysiological mechanisms underpinning behaviour change in fish}

In a landmark paper, Poulin (1994) discussed how an improved mechanistic understanding could give insight into the evolutionary basis of parasite-mediated host behaviour change, arguing that the discovery of direct neuro-manipulation mechanisms would provide strong evidence in favour of adaptive manipulation. Since then, neurobiologists and evolutionary behavioural biologists alike have become increasingly motivated to uncover these mechanisms, which may also shed light on 
fundamental aspects of the control of animal behaviour (Demas, Adamo, and French

411 2011; Beckage 1997; McCusker and Kelley 2013; Adamo 2012). Alongside

412 invertebrate models, fish have been featured significantly as hosts in these studies,

413 with much of the effort focused on a small number of experimental systems. Here we

414 discuss the insights from two of these study systems.

\subsubsection{Case study I: Mechanisms of behaviour change in Schistocephalus infected}

417 sticklebacks

418 Three-spined sticklebacks Gasterosteus aculeatus are frequently infected with

419 plerocercoids of the diphyllobothriidean cestode Schistocephalus solidus, with

420 infections being associated with a wide range of behavioural and physiological

421 changes (Barber 2007, 2013; Milinski 1990; Barber and Scharsack 2010). The

422 widespread distribution of the host and parasite in Europe, North America and beyond

423 (Wootton 1976), the suitability of sticklebacks for lab and field studies of behaviour

424 (Huntingford and Ruiz-Gomez 2009) and the dramatic effects of infection on host

425 phenotype have meant that behaviour change in this system has been well studied.

426 Early studies of naturally-infected fish documented a myriad of effects on

427 antipredator behaviour (Giles 1983; Milinski 1984, 1985; Tierney, Huntingford, and

428 Crompton 1993), shoaling behaviour (Barber, Huntingford, and Crompton 1995;

429 Barber, Downey, and Braithwaite 1998), position in the water column (Lobue and

430 Bell 1993; Lester 1971), and on respiration (Meakins and Walkey 1975), host

431 energetics (Arme and Owen 1967) and sexual development (Heins and Baker 2008).

432 The adoption of experimental in vitro parasite culture techniques originally developed

433 to study parasite biochemistry (Smyth 1990) opened up the stickleback-

434 Schistocephalus model for use as an experimental host-parasite system for the study 

Scharsack 2010). Subsequent studies have demonstrated that many of the effects associated with infection - including effects on antipredator behaviour, escape responses, habitat use and reproductive behaviours - are indeed caused by the parasite (Barber 2007, 2013). Attention is now turning to using the experimental model to examine the neurophysiological mechanisms underpinning the behavioural changes caused by infection. Schistocephalus plerocercoids attain a very large size relative to their hosts, and their growth - which is fuelled by host-derived nutrients - places host fish under severe energetic stress under normal, food limited conditions (Barber, Arnott, and Wootton 2008), which could have significant consequences for behaviour even in the absence of direct neurochemical manipulation by the parasite. A key question is therefore whether host behaviour changes constitute true 'manipulation' in other words, if they arise as a result of direct, adaptive manipulation of host behaviour by parasites - or whether they represent unavoidable side effects of 449 energetic drain caused by the growing worms.

Altered behaviour of infected sticklebacks is associated with altered monoamine neurotransmitters signatures in lobes of the brain. Among a wild-sampled population of sticklebacks, Schistocephalus infection was associated with significantly elevated HIAA:5-HT ratio in both the hypothalamus and brainstem, and a reduced concentration of 5-HT and NE in the telencephalon compared to controls (Øverli, 455 Páll, et al. 2001). While tempting to speculate that these patterns might imply direct manipulation of host neurochemistry by the parasite - perhaps by secreting biologically-active substances such as neurotransmitter analogues, receptor 458 antagonists or other substances that alter biosynthetic pathways or the epigenetic 459 control of neurotransmission that interact directly with the host's neuroendocrine 
system - these results are also consistent with a chronic stress response. Alternatively,

461 they might arise as a side effect of cryptic interplay between immune and

462 neuroendocrine systems.

463 One potentially insightful approach is to examine transcriptomic changes in

464 plerocercoids before and after the 50mg point - at which they attain infectivity to final

465 avian hosts (Tierney and Crompton 1992) and change the behaviour of host

466 sticklebacks (Tierney, Huntingford, and Crompton 1993; Barber, Walker, and

467 Svensson 2004) - to identify candidate parasite-synthesized molecules that could be

468 involved in host-parasite molecular 'cross-talk' (Hébert and Aubin-Horth 2014). The

469 development of a large transcriptomic dataset, spanning the pre-infective, post-

470 infective and adult stages of Schistocephalus worms, now provides a solid foundation

471 for such studies (Hébert et al. 2016). Hébert et al. (2015) identified 94 proteins, with

472 four of them being either secreted or membrane proteins from Schistocephalus that

473 showed high local sequence homology with stickleback proteins, which could

474 potentially act as signaling molecules to modulate host physiological pathways

475 involved in the control of behavioral phenotypes. These candidate proteins include a

476 member of the Wnt family of signaling molecules, which play an important role in

477 cell-to-cell interactions, and others that are involved in ion transport and post-

478 translational protein modification. Using a differential gene expression analysis,

479 Hébert et al. (submitted) were able to identify a large module of 407 co-expressed

480 genes that were significantly up-regulated in infective, compared to non-infective,

481 plerocercoids. The majority of the enriched genes with GO-annotations had functions

482 involved in cellular responses to drugs and neuromodulators, and secretion and

483 transport of various molecules through the cell membrane; however, this module was

484 also notable because the majority of these differentially expressed genes were un- 
annotated. For example, the top 15 most highly differentiated genes between preinfective and infective plerocercoids were all completely unknown, and all were Schistocephalus-specific, with no homology match to any known database except the S. solidus genome. These results provide tantalizing glimpses into how future studies may utilize genomic and post-genomic techniques to examine the molecular (epi)genetic basis of behaviour change; they also highlight the level of work still needed, for example, to assign functions to parasite genes.

An alternative to studying the proximate mechanisms directly is to examine the ultimate patterns of behaviour observed, to determine whether they are best explained by the adaptive or non-adaptive side effects hypotheses, and the utility of the stickleback-Schistocephalus system facilitates this approach. Recent studies have used elegant experimental infection approaches to generate a 'conflict' between coinfecting Schistocephalus plerocercoids, and have studied the behaviour of infected stickleback hosts to gain insight into the likely mechanisms. Hafer and Milinski (2016) used temporally-separated infections to generate stickleback hosts that

500 harboured two parasites, such that only the older co-infecting worm had attained a mass greater than the 50mg infectivity threshold. The behaviour of these host fish was compared with the behaviour of fish harbouring a single, infective worm. The prediction was, that if parasites manipulated behaviour directly, then the smaller severely in the 'conflict' fish. While this appears to provide evidence against adaptive parasite induced host 'manipulation', and supports the 'nutritional side effect' 
510 in co-infections, which grow more slowly than in single infections (Heins, Baker, and

511 Martin 2002), may switch to an alternative developmental strategy that permits

512 successful transmission at a smaller body size. Future studies will need to measure the

513 reproductive potential of single and co-infecting plerocercoids in order to relate the

514 consequences of host behaviour change more clearly to parasite fitness.

515 While a consensus has yet to be reached on the nature of the mechanism(s)

516 underpinning the behavioural changes in three-spined sticklebacks infected with

517 Schistocephalus solidus, this system is uniquely well-suited to such investigations,

518 and further studies are underway. The greatest insights seem likely to come from

519 studies that combine both the proximate and ultimate approaches, studying both the

520 mechanistic basis of behaviour change and the fitness implications for hosts and

521 parasites under naturalistic environmental conditions.

\subsubsection{Case study II: Digenean infections in the eyes and brains of teleost fish}

524 Parasites that locate in, or close to, sensory and neural tissues including the brain have 525 particular capacity to influence behaviour; indeed, the preferences of parasites for

526 these locations may have evolved at least in part because of the potential to 527 manipulate hosts.

528 Diplostomatid trematodes are parasites that infect birds as adults, and commonly 529 utilize fish as $2^{\text {nd }}$ intermediate hosts in their life cycle. Fish become infected when 530 free-swimming cercariae released from snails penetrate their skin, and the parasites 531 migrate to target locations through host blood vessels (Haas et al. 2007; Matisz and

532 Goater 2010; Matisz, Goater, and Bray 2010; Sandland and Goater 2000), before undergoing development to the metacercarial stage of development, which is infective 
534 to predatory birds. Some of these parasites (e.g. the Diplostomum spp. complex) target

535 various tissues of the fish eye, including the lens, vitreous humor and retina and

536 infections with these parasites are associated with reduced visual acuity in feeding

537 trials (Owen, Barber, and Hart 1993), most likely as a result of physical damage to

538 sensitive optical tissues. For example, dace (Leuciscus leuciscus) infected by

539 increasing numbers of Diplostomum spathaceum are less efficient foragers, and need

540 to spend more time foraging to compensate (Crowden and Broom 1980). Infected

541 trout are also more easily caught by humans with dip-nets (Seppälä, Karvonen, and

542 Valtonen 2005), and form smaller, less cohesive shoals than non-infected conspecifics

543 (Seppälä, Karvonen, and Valtonen 2008). Taken together, the effects on host visual

544 performance and behavior imply a higher susceptibility of host fish to predation by

545 surface-feeding birds, though this has yet to be conclusively demonstrated (Seppälä,

546 Karvonen, and Valtonen 2006). Cataract formation is commonly associated with

547 Diplostomum infection, and is likely the mechanism through which visual acuity is

548 reduced (Karvonen, Seppälä, and Valtonen 2004; Seppälä, Karvonen, and Valtonen

549 2011). Alternatively, trematodes residing in the eye could reduce visual acuity

550 directly by occluding the visual field. For example, Tylodelphys trematodes in the

551 eyes of common bully (Gobiomorphus cotidianus) remain unencysted and move in

552 front of the fish's visual field during the day, but not at night (Stumbo and Poulin

553 2016). Daytime obstruction of the common bully's visual field is believed to make

554 host fish more susceptible to predatory birds that forage during the day, while

555 allowing the fish to maintain vigilance against nighttime-foraging predatory fish

556 which are not suitable definitive predators for the parasite (Stumbo and Poulin 2016),

557 but additional studies are necessary to explore this hypothesis.

558 Other species - including Diplostomum phoxini, Orinthodiplostomum ptychocheilus, 
and Euhaplorchis californensis - target the brain, where they accumulate over the life of the fish and can achieve high densities on the surface and in various brain lobes (Matisz and Goater 2010; Matisz, Goater, and Bray 2010; Barber and Crompton 1997, 1997; Sandland and Goater 2000; Shaw et al. 2010). While Euhaplorchis species reside on the brain surface, species in the genera Diplostomum and Ornithodiplostomum tend to reside within their host's brain tissue; for example, Diplostomum phoxini infecting European minnows (Phoxinus phoxinus) tend to aggregate in the cerebellum, medulla oblongata, and optic lobes (Barber and Crompton 1997). Behavioral changes are likely associated with pathology, as the parasites appear to consume the host's brain tissue directly, compounds secreted by the parasite appear to degrade surrounding brain tissue, and the presence of hostderived rodlet cells suggests a neuroinflammatory response to infection (Dezfuli, Giari, and Shinn 2007; Dezfuli et al. 2007). Metacercariae of Ornithodiplostmum ptychocheilus infecting fathead minnows (Pimephales promelas) also initially aggregate in the cerebellum and optic lobes (Hendrickson 1979), and for about 28 days post-infection project microvilli that presumably are used to feed on host brain tissue (Goater, Bray, and Conn 2005). After 28 days post-infection, the trematodes migrate to the meninges, encyst, and stimulate the production of rodlet cells indicative of a host neuro-inflammatory response (Matisz, Goater, and Bray 2010). No changes in social behavior or antipredator behavior were noted in naturally infected fathead minnows (Wisenden et al. 2012). However, reduced optomotor responses in fathead minnows infected by O. ptycholcheilus have been observed (Shirakashi and Goater 2002). These behavioral changes likely reflect pathology as they are observable while the parasite is maturing but not when the parasite has matured and is competent to infect definitive hosts (Shirakashi and Goater 2005). 
584 California killifish are infected by metacercariae of a trematode parasite,

585 Euhaplorchis californiensis, which reside on the surface of the killifish brain.

586 Infection reaches near 100\% prevalence in the adult population (Shaw et al. 2010),

587 and infected killifish exhibit "conspicuous behaviors”, including darting to the surface

588 of the water and performing rapid body contortions, far more frequently than

589 uninfected killifish (Lafferty and Morris 1996). The frequency of conspicuous

590 behaviors increases with E. californiensis infection intensity, and infected fish are 10-

59130 times more likely to be consumed by predatory birds, which are the definitive

592 hosts of E. californiensis (Lafferty and Morris 1996). In both wild-caught and

593 naturally infected killifish, E. californiensis infection is associated with parasite

594 density-dependent decreases in serotonergic activity in the hippocampus (Shaw et al.

595 2009; Shaw and Øverli 2012). Additionally, while teleost fish frequently exhibit an

596 increase in serotonergic metabolism in the raphe nuclei in response to stress, infection

597 appears to dampen this response (Shaw et al. 2009). In fish, serotonin is associated

598 with reduced aggression and locomotor activity (Winberg and Nilsson 1993). While

599 direct links between serotonergic activity and conspicuous behaviors have yet to be

600 established, these results suggest that E. californiensis may induce conspicuous

601 behaviors (which are largely locomotory) through suppression of the host serotonergic 602 system.

\subsection{Host behaviour change in the context of animal personalities and behavioural}

605 syndromes

606 Since the adoption of the animal personality paradigm by ethologists and behavioural

607 ecologists, a small number of studies have attempted to investigate the effects of

608 parasite infections on fish behaviour using these approaches. These studies have 
609 addressed two major themes; the effects of parasite infections on the temporal

610 consistency of host behaviour, and on the relationships between behaviours among

611 infected, compared to non-infected, sub-populations of fish. Parasites have been

612 suggested to increase or decrease temporal consistency of host behaviour following

613 infection, as a result of damage or manipulation of sensory or motor systems that

614 could either generate more erratic behaviour, or channelize host responses to be less

615 variable; similarly, it has been suggested that parasites could either generate /

616 strengthen or weaken / decouple existing behavioural syndromes, if this gives them a

617 selective benefit, for example in terms of enhancing transmission to susceptible

618 predators (Barber and Dingemanse 2010; Poulin 2010; Poulin 2013).

619 Hammond-Tooke et al. (2012) studied the activity, aggression and boldness of wild-

620 caught common bullies (Gobiomorphus cotidianus) that varied naturally in their

621 infection levels with four different trematode parasites. Behaviour was tested in the

622 presence and absence of a predator cue, and the repeatability of - and correlations

623 among - behaviours were quantified. Multiple uncontrolled co-infections made it

624 difficult to interpret the results of the study, but one interesting result was that

625 temporal consistency of activity tended to be related negatively to infection levels. As

626 the study used naturally infected fish, it was not possible to determine whether fish

627 showing greater consistently in their activity levels were less susceptible to infection,

628 or whether higher levels of infection generate greater within-individual variation in

629 activity; either appear possible, and experimental studies would be required to gain

630 further insights.

631 Recognizing the potential for experimental infection studies to provide detail on

632 mechanisms, Kekäläinen et al. (2014) compared the boldness, activity and exploration

633 behaviour of European minnows Phoxinus phoxinus that had been experimentally 
634 infected with the brain-dwelling trematode Diplostomum phoxini with that of shamexposed controls. Their results showed that while there were no differences in mean

636 behavioural values, infected fish showed higher repeatability in boldness and activity, 637 and lower repeatability in exploration than controls, and there was some evidence that 638 - among fish harboring the highest levels of infections - that the boldness-exploration syndrome exhibited by non-infected fish might break down. However, the documented effects of infection on host personality are not consistent between study systems. In a similar study involving rainbow trout being exposed to controlled doses of Diplostomum pseudospathaceum, which develops in the eye rather than the brain

643 of the host fish, infected fish were found to be less bold than controls - suggesting a 644 single-axis effect on behaviour - but there was no difference between parasitized and control fish in terms of the temporal consistency of, or relationships between,

646 individual behaviours (Klemme, Kortet, and Karvonen 2016). Further experimental 647 studies are now needed to test the generality of the finding that parasite infections can 648 have implications for the temporal and cross-contextual consistency of behaviour, to 649 gain greater insights into wider implications of infection for the ecology and evolution 650 of behaviour.

\section{Personality, cognition and the potential for interaction with parasites}

653 Cognition has been defined as the acquisition, processing, storage and use of 654 information (Shettleworth 2010). In recent years, there has been a surge of interest in 655 relationships between personality and cognition in non-human animals (Griffin, 656 Guillette, and Healy 2015; Sih and del Giudice 2012). A long established idea is that 657 the proactive-reactive axis is associated with both personality traits and learning 658 tendencies (Coppens, de Boer, and Koolhaas 2010). Proactive animals tend to be 
659 bolder and more aggressive, but less sensitive to and thus slower to learn about

660 changes in their environment. Sih \& Del Giudice (2012) built on this idea to outline a

661 series of hypotheses on relationships between behavioural types and cognitive styles.

662 They first noted, as have others, that behavioural types fall along a 'fast-slow', risk-

663 reward continuum where fast behavioural types (bolder, more active, more

664 aggressive, more exploratory) take greater risks to gain greater rewards (compared to

665 slow behavioural types). They then added that cognitive styles can also be arrayed

666 along a fast-slow continuum based on a speed-accuracy tradeoff where rapid

667 decisions, based perhaps on less information collection, and faster, less careful

668 processing would tend to be less accurate. Putting these two simple generalities

669 together yielded the prediction that proactive, fast-exploring, bold, aggressive animals

670 would tend to be more impulsive, less choosy, and more risk prone. With regard to

671 learning, predictions on personality and learning depend on the type of task. Sih and

672 Del Giudice (2012) predicted that fast, high risk, high reward personality types would

673 learn new activity-based tasks more quickly, but would be slower to learn avoidance

674 tasks and slower at reversal learning.

675 Since 2012, numerous studies have tested these predictions, including studies on fish

676 (Mamuneas et al. 2015; DePasquale et al. 2014; Kotrschal et al. 2014; Trompf and

677 Brown 2014), and have found mixed results. Griffin et al. (2015) noted, however, the

678 logistical challenges associated with conducting a proper test of relationships between

679 personality and cognition, and concluded that to their knowledge, no studies have yet

680 fulfilled their criteria for testing Sih and Del Giudice (2012)’s hypotheses.

681 Although the 'jury is still out' on whether we are making progress towards a general

682 theory on individual differences in personality and cognition, here we outline two

683 major areas in which cognitive science might be linked to host-parasite interactions. 
684 First, we suggest that pre-existing individual variation in cognitive ability, potentially 685 linked to variation in personality or behavioural 'type', may have implications for 686 infection susceptibility. Second, we examine the possibility for infections to interfere 687 with host cognitive function.

\subsection{Avoiding infections}

690 Here we explore a number of different routes through which variation in cognition might influence parasitism. Fish can use visual and other cues to detect parasite infections and use the information to make avoidance decisions. For example, sticklebacks can detect ectoparasitic Argulus spp. lice and actively avoid vegetation infested with the parasites; furthermore, these fish also avoid habitat types associated with increased risk of Argulus infection, even in the absence of the parasites themselves (Poulin and Fitzgerald 1989). For parasites that infect fish hosts by penetrating the skin, chemicals released from the damaged epithelium can be used by fish to identify and avoid risky habitats (Chivers et al. 2007). Given their clear potential to significantly impact fitness, many of the cognitive mechanisms by which

700 fish identify and avoid predators and/or high predation risk habitats, including the use 701 of social cues (Brown and Laland 2003), are also expected to be used in parasite detection.

703 Following the Sih and Del Giudice (2012) hypothesis on relationships between riskreward tradeoffs, fast-slow behavioural types and speed-accuracy cognitive styles, we hypothesize that bolder, more aggressive, more exploratory animals might not only tend to encounter more parasites (e.g., by using a broader range of habitats including those with more parasites), they might also be slower to learn to avoid situations 
associated with high parasite risk. That is, they might be less attentive to cues associated with parasites, and slower to learn cues or habitats associated with higher parasite risk.

Interestingly, an alternative framework suggests the opposite conclusion: that faster behavioural types should be quicker to learn to avoid parasites. If faster behavioural types are more likely (than slow ones) to encounter parasites and if parasites can be very costly, then these bold, exploratory animals should have had stronger selection favoring the evolution or development of a stronger tendency to learn cues that would help them avoid parasites. Or, even if personalities do not differ in their tendency to learn from experience with parasites, if faster behavioural types simply have more experience with parasites, they should have a higher likelihood of learning to avoid situations with high parasite risk. Recent experimental evidence in support of this hypothesis has been provided by Klemme and Karvonen (2016) who demonstrated that bolder sea trout Salmo trutta performed better in learning tests than shy individuals, suggesting that an increased investment in cognitive ability may be an adaptive compensatory response of individuals with 'faster' behavioural types that are more likely to encounter infective parasites.

An interesting ‘special case’ involves socially-transmitted parasites. Animals, including fish, frequently differ in sociability (e.g. Cote et al. 2010). More social animals are more likely to be found in larger schools where they might be exposed to more parasites; however, if sociality is associated with higher parasite risk, social individuals should also be more attuned to, and faster to learn to avoid specific situations associated with risk of parasite transmission.

To date, few studies have tested these contrasting predictions, but we suggest that fish may provide ideal models for the subsequent development of this field. Intriguingly, 
733 because host-parasite interactions are dynamic, predictions on associations between

734 personality, cognition and parasites might depend not just on how personality and

735 cognition relate to host responses to parasites, but vice versa on how parasites affect

736 personality and cognition. We earlier discussed how parasites influence host

737 personalities; we next discuss how they might also affect host cognition.

738

739

740

741 The effects of parasite infections, or their associated consequences for immune

\subsection{Impacts of infections on cognitive processes: Does infection affect learning and} memory in fish?

stimulation, on cognitive processes have been widely studied in mammals, including humans (Sternberg et al. 1997), and some invertebrate model systems. For example, honeybees (Apis mellifera) that receive a non-pathogenic stimulant to the immune system have a reduced ability to associate an odour with a sugar reward (Mallon et al., 2003) and bumblebees (Bombus terrestris) whose immune systems are experimentally challenged perform worse in memory tests than healthy bees (Riddell and Mallon, 2006). This suggests a trade-off between high functioning immune systems and increased learning and memory. Kavaliers and Colwell (1995) found mice (Mus spp.) infected with the nematode Heligmosomoides polygyrus had reduced spatial learning ability, and mice infected with T. gondii are also shown to have impaired learning (Hodkova et al., 2007), though it is unclear whether this is due to an impaired ability to recognise the learning stimuli, or learning ability per se.

Fish exhibit the full range of cognitive abilities, as discussed extensively in this volume and elsewhere (Brown, Laland, and Krause 2011), and are particularly well studied in the context of social learning, cooperation and spatial learning (Bshary and 
Brown 2014). Despite this, we are aware of no published studies that have yet examined the implications of parasite infections for the cognitive abilities of fish. Again, we suggest that many of the experimentally-amenable, laboratory fish-parasite systems that exist offer ideal opportunities to investigate the implications of infections for cognitive function, both at a mechanistic basis and also in terms of the ecological consequences of parasite-induced changes. Zebrafish (Danio rerio), which are wellestablished as models for experimental cognitive neuroscience (Oliveira 2013; Spence, Magurran, and Smith 2011), have been used to examine the mechanistic basis and functional aspects of personality (Kern et al. 2016; Martins and Bhat 2014; Norton et al. 2011), and are frequently infected in laboratory facilities with parasites that have reported effects on behaviour (Spagnoli, Sanders, and Kent 2016; Spagnoli, Xue, and Kent 2015), might be especially well suited for the future development of this exciting research direction.

\subsection{Parasites, cognition and environmental heterogeneity}

As well as conferring potential fitness benefits (Dukas and Bernays 2000), cognitive function also incurs costs, including energetic costs associated with forming and retrieving information (Dukas 1999) and opportunity costs (Sih 1992). As a consequence, behaviours that rely on advanced cognitive abilities are expected to evolve only in environments in which they provide adaptive value (Niemelä et al. 2013). In the context of our review, in environments that offer a uniform, persistent threat of parasite infection, the costs of cognitively-demanding behaviours may not be sufficiently covered by the associated benefits. Similarly, in environments where the risk of infection is highly unpredictable over temporal or spatial scales, there may be little selection for cognitively-demanding behaviours. On the other hand, selection for 
such behaviours might be expected to be strong in environments where the threat of infection is moderate and intermediately variable. Furthermore, following arguments proposed by Niemelä et al. (2013), such environmental differences may also have implications for individual flexibility versus consistency of cognitively-demanding behaviours. While these hypotheses remain untested in the context of host-parasite interactions, we suggest that fish may prove excellent models for testing these ideas within an experimental framework.

\section{Conclusions}

The overarching aim of our review has been to examine the range of mechanisms that may engender links between fish behavior and parasite infections, specifically by exploring the different stages of the host-parasite interaction: exposure, infection probability given exposure, and phenotypic changes post-infection. Within these, we consider the roles played by neuro-, immune, and physiological systems, as well as their interplay. It is clear that we are only beginning to uncover the details of the extent of mechanisms that are involved, and that there is still a dearth of knowledge about how fish personalities and parasitism interact, even in well-studied model systems. While post-infection effects on host phenotypes have been relatively well studied, how pre-infection behaviour (and personality) affects infection susceptibility - and how this influences post-infection changes - remains largely unknown.

Similarly, how changes affect personality, rather than simply behavior, is also only now starting to be investigated.

The suitability of many fish species both as model hosts for experimental parasitology and for behavioural research means they are well positioned for studying the 
proximate mechanisms underlying the many links between host behaviour and infection status, potentially allowing cause, consequence, and corollary to be separated in controlled laboratory studies. Such studies will increase our understanding of interactions between the endocrine, immune, and neuronal systems and pave the way toward a more integrated understanding of the mechanistic basis of personality variation. Mechanistic studies of behaviour manipulating parasites may prove particularly insightful in this regard, by potentially revealing the mechanistic basis of personality. In particular, new genomic and post-genomic tools offer exciting opportunities to delve far more deeply into the proximate mechanisms underpinning behavioural manipulation by parasites. Despite the availability of well-suited fish model systems, the role of cognition has been studied little in the context of parasitism, and almost not at all in combination with personality; we suggest this as an area that could rapidly expand and offer considerable opportunities for productive research.

As model species, fish provide many benefits regarding accomplishing these research goals. Their behaviours in the lab are well characterized, many species have published genomes, their physiology, endocrinology and immunology is readily studied and well characterized, and a number of useful, ecologically-relevant experimental hostparasite systems have been developed to facilitate controlled lab studies. Taken together, this means that fish-parasite models may require little "overhead” work before targeted experiments can be used to gain information on these aforementioned topics. To conclude, fishes appear to be good model organisms for studying the role of behaviour, personality and cognition at all stages of the host-parasite interaction. In the process we are likely to learn more about the mechanistic bases underpinning not only parasite-host interactions, but the fundamental proximate mechanisms 
831 underlying behavior and personality.

832

833

\section{Acknowledgements}

835 We are grateful to Nadia Aubin-Horth for comments on parts of the manuscript, and

836 to two referees for insight and suggestions. IB is grateful to the UoL for a short

837 sabbatical that permitted the initial collaborative visit to UC Davis. ABM was funded

838 by a Postdoctoral Research Fellowship in Biology by the National Science

839 Foundation (Award \#152394). KLW was funded by a Huxley Faculty Fellowship in

840 Ecology and Evolutionary Biology from Rice University. AS is grateful to the US

841 National Science Foundation for research funding (NSF DEB 1456730).

842 
844 Figure 1 Schematic diagram illustrating the major conceptual relationships linking

845 individual differences in fish behaviour and / or personality to parasite infection. (1)

846 Pre-existing differences in behaviour or personality influence exposure to infective

847 parasites [Section 2.1]. (2) Pre-existing differences in behaviour or personality

848 influence the probability of infection independently of any effect on exposure, as a

849 result of (e.g.) underpinning immuno-physiological variation among hosts [Section

850 2.2]. (3) Pre-existing differences in behaviour or personality influence the growth,

851 development or proliferation of parasites, or of host responses to established parasites,

852 affecting the 'infection phenotype' of fish [Section 2.3]. (4) Infection per se alters

853 host behaviour or personality [Section 3]. (5) Infection phenotype influences host

854 behaviour or personality [Section 3].

855

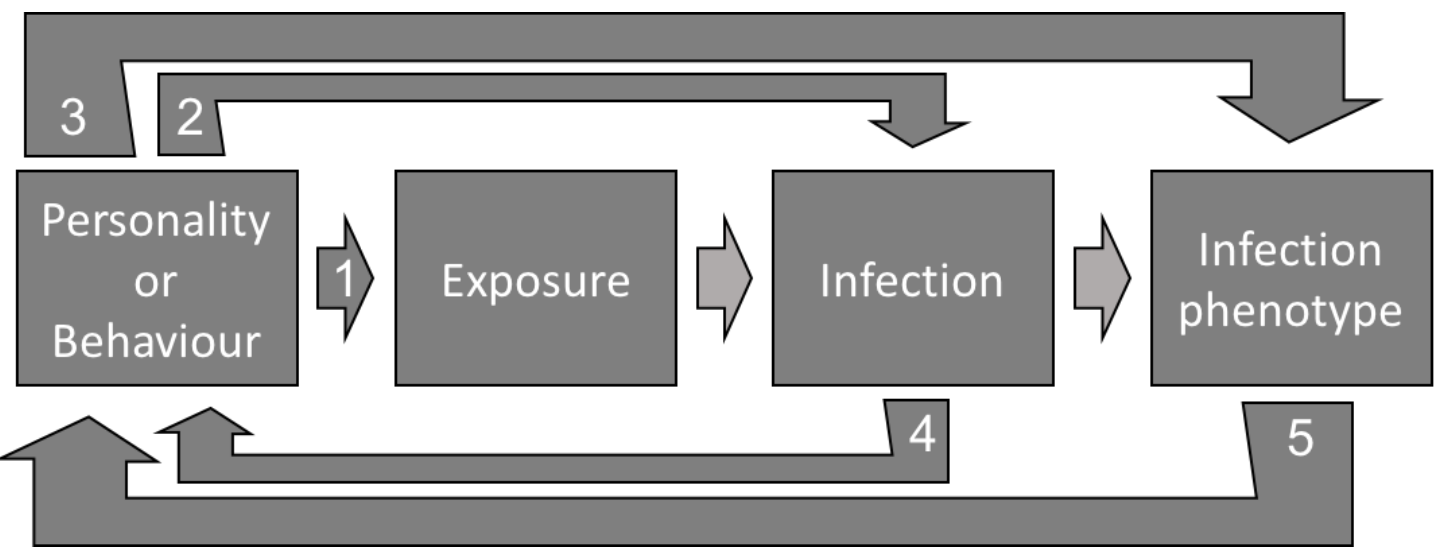


857 Table 1. Selected examples of fish behaviour change associated with parasite infection, chosen to highlight the diversity of behaviours affected,

858 the range of infections studied and the mechanisms proposed.

\begin{tabular}{|c|c|c|c|c|c|c|}
\hline $\begin{array}{l}\text { Behaviour } \\
\text { category }\end{array}$ & Host & Parasite & $\begin{array}{l}\text { Behavioural change } \\
\text { observed }\end{array}$ & $\begin{array}{l}\text { Proposed } \\
\text { physiological } \\
\text { mechanism of } \\
\text { behavioural change }\end{array}$ & $\begin{array}{l}\text { Experimental } \\
\text { or natural } \\
\text { infection }\end{array}$ & Reference(s) \\
\hline Aggression & $\begin{array}{l}\text { Rainbow trout } \\
\text { (Oncorhynchus } \\
\text { mykiss) }\end{array}$ & $\begin{array}{l}\text { Diplostomum } \\
\text { spathaceum } \\
\text { (Trematoda) }\end{array}$ & $\begin{array}{l}\text { Reduced aggression when } \\
\text { parasites pre-infective, } \\
\text { increased aggression } \\
\text { when parasites became } \\
\text { infective }\end{array}$ & $\begin{array}{l}\text { Not tested } \\
\text { (parasite encysts in eye } \\
\text { lens, inducing cataract } \\
\text { formation and vision } \\
\text { loss) }\end{array}$ & Experimental & (Mikheev et al. 2010) \\
\hline Aggression & $\begin{array}{l}\text { Common bullies } \\
\text { (Gobiomorphus } \\
\text { cotidianus) }\end{array}$ & $\begin{array}{l}\text { Apatemon sp. } \\
\text { (Trematoda) }\end{array}$ & $\begin{array}{l}\text { Infection loads positively } \\
\text { associated with } \\
\text { aggression }\end{array}$ & Not tested & Natural & $\begin{array}{l}\text { (Hammond-Tooke, } \\
\text { Nakagawa, and Poulin } \\
\text { 2012) }\end{array}$ \\
\hline
\end{tabular}




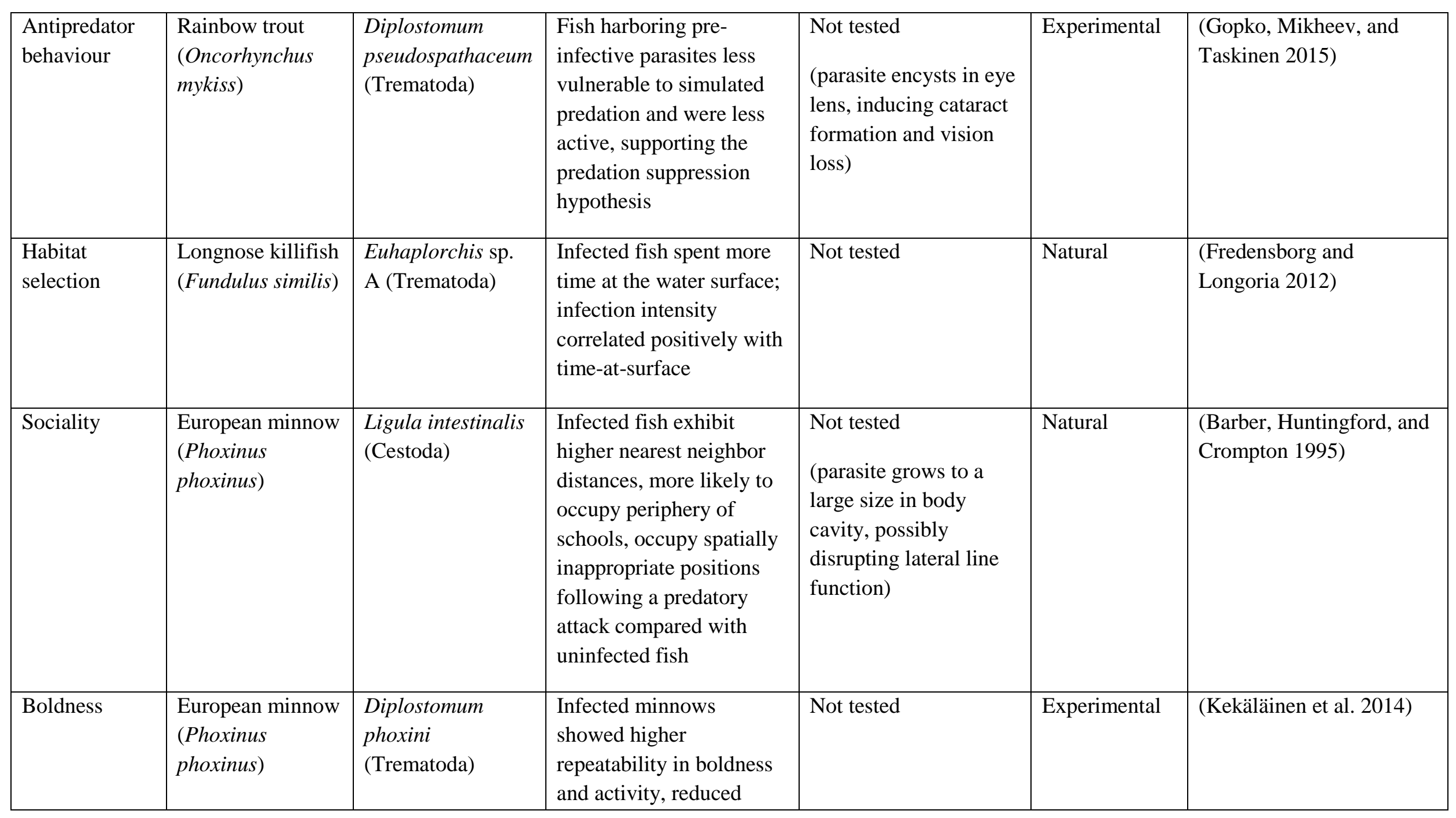




\begin{tabular}{|c|c|c|c|c|c|c|}
\hline & & & $\begin{array}{l}\text { repeatability in } \\
\text { exploration behavior }\end{array}$ & & & \\
\hline Boldness & $\begin{array}{l}\text { Rainbow trout } \\
\text { (Oncorhynchus } \\
\text { mykiss) }\end{array}$ & $\begin{array}{l}\text { Diplostomum } \\
\text { pseudospathaceum } \\
\text { (Trematoda) }\end{array}$ & $\begin{array}{l}\text { Infected trout were less } \\
\text { bold than control fish }\end{array}$ & Not tested & Experimental & $\begin{array}{l}\text { (Klemme, Kortet, and } \\
\text { Karvonen 2016) }\end{array}$ \\
\hline $\begin{array}{l}\text { Antipredator } \\
\text { behaviour }\end{array}$ & $\begin{array}{l}\text { Three-spined } \\
\text { stickleback } \\
\text { (Gasterosteus } \\
\text { aculeatus) }\end{array}$ & $\begin{array}{l}\text { Schistocephalus } \\
\text { solidus (Cestoda) }\end{array}$ & $\begin{array}{l}\text { Infected fish returned to } \\
\text { food patches more } \\
\text { quickly than uninfected } \\
\text { conspecifics following a } \\
\text { simulated predator attack }\end{array}$ & Not tested & Natural & Giles 1983 \\
\hline Sociality & $\begin{array}{l}\text { Three-spined } \\
\text { stickleback } \\
\text { (Gasterosteus } \\
\text { aculeatus) }\end{array}$ & $\begin{array}{l}\text { Schistocephalus } \\
\text { solidus (Cestoda) }\end{array}$ & $\begin{array}{l}\text { Infected fish more likely } \\
\text { to leave shoals to forage } \\
\text { than uninfected fish }\end{array}$ & Not tested & Natural & $\begin{array}{l}\text { (Barber, Huntingford, and } \\
\text { Crompton 1995) }\end{array}$ \\
\hline
\end{tabular}




\begin{tabular}{|c|c|c|c|c|c|c|}
\hline $\begin{array}{l}\text { Antipredator } \\
\text { behaviour }\end{array}$ & $\begin{array}{l}\text { Three-spined } \\
\text { stickleback } \\
\text { (Gasterosteus } \\
\text { aculeatus) }\end{array}$ & $\begin{array}{l}\text { Schistocephalus } \\
\text { solidus (Cestoda) }\end{array}$ & $\begin{array}{l}\text { Infected fish feed in } \\
\text { closer proximity to a live } \\
\text { cichlid predator } \\
\text { compared with uninfected } \\
\text { fish }\end{array}$ & Not tested & Natural & (Milinski 1985) \\
\hline Foraging & $\begin{array}{l}\text { Three-spined } \\
\text { stickleback } \\
\text { (Gasterosteus } \\
\text { aculeatus) }\end{array}$ & $\begin{array}{l}\text { Diplostomum } \\
\text { pseudospathaceum } \\
\text { (Trematoda) }\end{array}$ & $\begin{array}{l}\text { Infected fish experience } \\
\text { reduced visual acuity, } \\
\text { shorter reactive distance } \\
\text { to prey }\end{array}$ & $\begin{array}{l}\text { Not tested } \\
\text { (parasite encysts in eye } \\
\text { lens, inducing cataract } \\
\text { formation and vision } \\
\text { loss) }\end{array}$ & Natural & $\begin{array}{l}\text { (Owen, Barber, and Hart } \\
\text { 1993) }\end{array}$ \\
\hline Competition & $\begin{array}{l}\text { Three-spined } \\
\text { stickleback } \\
\text { (Gasterosteus } \\
\text { aculeatus) }\end{array}$ & $\begin{array}{l}\text { Schistocephalus } \\
\text { solidus (Cestoda) }\end{array}$ & $\begin{array}{l}\text { Infected fish display } \\
\text { lower competitive ability } \\
\text { compared with uninfected } \\
\text { conspecific }\end{array}$ & $\begin{array}{l}\text { Not tested } \\
\text { (parasite encysts in eye } \\
\text { lens, inducing cataract } \\
\text { formation and vision } \\
\text { loss) }\end{array}$ & Natural & (Barber and Ruxton 1998) \\
\hline $\begin{array}{l}\text { Antipredator } \\
\text { behaviour }\end{array}$ & $\begin{array}{l}\text { California killifish } \\
\text { (Fundulus } \\
\text { parvipinnis) }\end{array}$ & $\begin{array}{l}\text { Euhaplorchis } \\
\text { californiensis } \\
\text { (Trematoda) }\end{array}$ & $\begin{array}{l}\text { Fish with higher infection } \\
\text { intensities perform more } \\
\text { conspicuous swimming } \\
\text { behaviors than fish with } \\
\text { fewer parasites }\end{array}$ & $\begin{array}{l}\text { Reduced 5-HT and } \\
\text { increased DA activity } \\
\text { in brainstems of } \\
\text { infected fish }\end{array}$ & $\begin{array}{l}\text { Natural and } \\
\text { Experimental }\end{array}$ & $\begin{array}{l}\text { (Lafferty and Morris } \\
\text { 1996; Shaw et al. 2010; } \\
\text { Shaw et al. 2009) }\end{array}$ \\
\hline
\end{tabular}




\begin{tabular}{|c|c|c|c|c|c|c|}
\hline $\begin{array}{l}\text { Antipredator } \\
\text { behaviour }\end{array}$ & $\begin{array}{l}\text { Roach (Rutilus } \\
\text { rutilus) }\end{array}$ & $\begin{array}{l}\text { Ligula intestinalis } \\
\text { (Cestoda) }\end{array}$ & $\begin{array}{l}\text { Compared with } \\
\text { uninfected fish, infected } \\
\text { fish preferred upper water } \\
\text { layer and surfaced more } \\
\text { readily following } \\
\text { simulated predatory } \\
\text { stimulus }\end{array}$ & Not tested & Natural & (Loot et al. 2001) \\
\hline $\begin{array}{l}\text { Reproductive } \\
\text { behaviour }\end{array}$ & $\begin{array}{l}\text { Three-spined } \\
\text { stickleback } \\
\text { (Gasterosteus } \\
\text { aculeatus) }\end{array}$ & $\begin{array}{l}\text { Schistocephalus } \\
\text { solidus (Cestoda) }\end{array}$ & $\begin{array}{l}\text { Infected males less likely } \\
\text { to build nests and court } \\
\text { females }\end{array}$ & $\begin{array}{l}\text { Reduced levels of } \\
\text { circulating 11-KT in } \\
\text { infected makes }\end{array}$ & $\begin{array}{l}\text { Natural / } \\
\text { Experimental }\end{array}$ & $\begin{array}{l}\text { (Macnab et al. 2011; } \\
\text { Macnab, Katsiadaki, and } \\
\text { Barber 2009; Candolin } \\
\text { and Voigt 2001) }\end{array}$ \\
\hline $\begin{array}{l}\text { Reproductive } \\
\text { behaviour }\end{array}$ & $\begin{array}{l}\text { Two-spotted goby } \\
\text { (Gobiusculus } \\
\text { flavescens) }\end{array}$ & $\begin{array}{l}\text { Kabatana spp. } \\
\text { (Microsporidia) }\end{array}$ & $\begin{array}{l}\text { Infected males courted } \\
\text { females less intensely }\end{array}$ & $\begin{array}{l}\text { Not tested } \\
\text { (parasite encysts and } \\
\text { destroys musculature) }\end{array}$ & Natural & (Pélabon et al. 2005) \\
\hline $\begin{array}{l}\text { Migratory } \\
\text { behaviour }\end{array}$ & $\begin{array}{l}\text { Gudgeon (Gobio } \\
\text { gobio) }\end{array}$ & $\begin{array}{l}\text { Ligula intestinalis } \\
\text { (Cestoda) }\end{array}$ & $\begin{array}{l}\text { Infected fish delayed } \\
\text { migrations to deeper } \\
\text { water at end of summer }\end{array}$ & Not tested & Natural & (Bean and Winfield 1989) \\
\hline $\begin{array}{l}\text { Migratory } \\
\text { behaviour }\end{array}$ & $\begin{array}{l}\text { Three-spined } \\
\text { stickleback } \\
\text { (Gasterosteus } \\
\text { aculeatus) }\end{array}$ & $\begin{array}{l}\text { Schistocephalus } \\
\text { solidus (Cestoda) }\end{array}$ & $\begin{array}{l}\text { Infected fish did not show } \\
\text { same diel vertical } \\
\text { movement as non- } \\
\text { infected fish; } \\
\text { overrepresented in trawl }\end{array}$ & Not tested & Natural & (Quinn et al. 2012) \\
\hline
\end{tabular}




\begin{tabular}{|c|c|c|c|c|c|c|}
\hline & & & $\begin{array}{l}\text { samples taken from the } \\
\text { surface during the day }\end{array}$ & & & \\
\hline $\begin{array}{l}\text { Thermal } \\
\text { choice }\end{array}$ & $\begin{array}{l}\text { Three-spined } \\
\text { stickleback } \\
\text { (Gasterosteus } \\
\text { aculeatus) }\end{array}$ & $\begin{array}{l}\text { Schistocephalus } \\
\text { solidus (Cestoda) }\end{array}$ & $\begin{array}{l}\text { Fish infected with } \\
\text { infective parasites } \\
\text { preferred warmer } \\
\text { temperatures than non- } \\
\text { infected controls }\end{array}$ & $\begin{array}{l}\text { Not tested } \\
\text { (Parasites grow faster } \\
\text { at warmer } \\
\text { temperatures, } \\
\text { suggesting parasite } \\
\text { manipulation) }\end{array}$ & $\begin{array}{l}\text { Natural / } \\
\text { experimental }\end{array}$ & $\begin{array}{l}\text { (Macnab and Barber } \\
\text { 2012) }\end{array}$ \\
\hline $\begin{array}{l}\text { Thermal } \\
\text { choice }\end{array}$ & $\begin{array}{l}\text { Guppy (Poecilia } \\
\text { reticulata) }\end{array}$ & $\begin{array}{l}\text { Gyrodactylus } \\
\text { turnbulli } \\
\text { (Monogenea) }\end{array}$ & $\begin{array}{l}\text { Infected fish preferred } \\
\text { warmer temperatures than } \\
\text { non-infected controls }\end{array}$ & $\begin{array}{l}\text { Not tested } \\
\text { (Parasite infection level } \\
\text { decreased at warmer } \\
\text { temperatures, } \\
\text { suggesting self- } \\
\text { medication by hosts }\end{array}$ & Experimental & $\begin{array}{l}\text { (Bean and Winfield 1989; } \\
\text { Macnab and Barber 2012; } \\
\text { Mohammed et al. 2016) }\end{array}$ \\
\hline
\end{tabular}


860

861

862

863

864

865

866

867

868

869

870

871

872

873

874

875

876

877

878

879

880

881

882

883

884

885

886

887

888

889

890

891

892

893

\section{References}

Aalvik, I.M., Moland, E., Olsen, E.M. and Stenseth, N.C. 2015. Spatial ecology of coastal Atlantic cod Gadus morhua associated with parasite load. Journal of Fish Biology, 87: 449-464.

Abbott, J.C. and Dill, L.M. 1985. Patterns of aggressive attack in juvenile steelhead trout (Salmo gairdneri). Canadian Journal of Fisheries and Aquatic Sciences, 42: 17021706.

Adamo, S.A. 2012. The strings of the puppet master: how parasites change host behaviour. In: D. Hughes, J. Brodeur and F. Thomas (Editors), Host Manipulation by Parasites, Oxford University Press, Oxford.

Adamo, S.A. 2013. Parasites: evolution’s neurobiologists. Journal of Experimental Biology, 216: 3-10.

Adamo, S.A. and Webster, J.P. 2013. Neural parasitology: how parasites manipulate host behaviour. Journal of Experimental Biology, 216: 1-2.

Arme, C. and Owen, R.W. 1967. Infections of the three spined stickleback, Gasterosteus aculeatus L., with the plerocercoid larvae of Schistocephalus solidus (Muller, 1776), with special reference to pathological effects. Parasitology, 57: 301-314.

Aubin-Horth, N., Deschênes, M. and Cloutier, S. 2012. Natural variation in the molecular stress network correlates with a behavioural syndrome. Hormones and Behavior, 61: 140-146.

Barber, I. 2005. Parasites grow larger in faster growing fish hosts. International Journal for Parasitology, 35: 137-143.

— 2007. Host-parasite interactions of the three-spined stickleback. In: S. ÖstlundNilsson, I. Mayer and F.A. Huntingford (Editors), Biology of the Three-Spined Stickleback CRC Press, Boca Raton, FL.

- 2013. Sticklebacks as model hosts in ecological and evolutionary parasitology. Trends in Parasitology, 29: 556-566.

Barber, I., Arnott, S.A. and Wootton, R.J. 2008. Growth and energetics in the sticklebackSchistocephalus host-parasite system: a review of experimental infection studies. Behaviour, 145: 647-668.

Barber, I. and Crompton, D.W.T. 1997. The distribution of the metacercariae of Diplostomum phoxini in the brain of minnows, Phoxinus phoxinus. Folia Parasitologica, 44: 19-25. . 1997. The ecology of Diplostomum phoxini infections in two minnow (Phoxinus phoxinus) populations in Scotland. Journal of Helminthology, 71: 189-196. 
Barber, I. and Dingemanse, N.J. 2010. Parasitism and the evolutionary ecology of animal personality. Philosophical Transactions of the Royal Society B-Biological Sciences, 365: 4077-4088.

Barber, I., Downey, L.C. and Braithwaite, V.A. 1998. Parasitism, oddity and the mechanism of shoal choice. Journal of Fish Biology, 53: 1365-1368.

Barber, I., Hoare, D. and Krause, J. 2000. Effects of parasites on fish behaviour: a review and evolutionary perspective. Reviews in Fish Biology and Fisheries, 10: 131-165.

Barber, I., Huntingford, F.A. and Crompton, D.W.T. 1995. The effect of hunger and cestode parasitism on the shoaling decisions of small freshwater fish. Journal of Fish Biology, 47: 524-536.

Barber, I. and Rushbrook, B.J. 2008. Parasites and fish behaviour. In: C. Magnhagen, V. Braithwaite, E. Forsgren and B.G. Kapoor (Editors), Fish Behaviour Science Publishers, Enfield, NH.

Barber, I. and Ruxton, G.D. 1998. Temporal prey distribution affects the competitive ability of parasitized sticklebacks. Animal Behaviour, 56: 1477-1483.

Barber, I. and Scharsack, J.P. 2010. The three-spined stickleback - Schistocephalus solidus system: an experimental model for investigating host-parasite interactions in fish. Parasitology, 137: 411-424.

Barber, I., Walker, P. and Svensson, P.A. 2004. Behavioural responses to simulated avian predation in female three spined sticklebacks: The effect of experimental Schistocephalus solidus infections. Behaviour, 141: 1425-1440.

Barber, I. and Wright, H.A. 2006. Effects of parasite on fish behaviour: interactions with host physiology. In: K. Sloman, R. Wilson and S. Balshine (Editors), Behaviour and physiology of fish, Elsevier, Amsterdam.

Barnard, C.J. and Behnke, J.M. 1990. Parasitism and host behaviour, CRC Press.

Bean, C.W. and Winfield, I.J. 1989. Biological and ecological effects of a Ligula intestinalis (L) infestation of the gudgeon, Gobio gobio (L), in Lough Neagh, Northern Ireland. Journal of Fish Biology, 34: 135-147.

Beckage, N.E. 1997. Parasites and pathogens: effects on host hormones and behavior Chapman \& Hall, New York.

Bell, A.M. 2005. Behavioural differences between individuals and two populations of stickleback (Gasterosteus aculeatus). Journal of Evolutionary Biology, 18: 464-473.

Biron, D.G. and Loxdale, H.D. 2013. Host-parasite molecular cross-talk during the manipulative process of a host by its parasite. Journal of Experimental Biology, 216: 148-160.

Bordes, F., Morand, S., Kelt, D.A. and Van Vuren, D.H. 2009. Home range and parasite diversity in mammals. American Naturalist, 173: 467-474. 
Boyer, N., Reale, D., Marmet, J., Pisanu, B. and Chapuis, J.L. 2010. Personality, space use and tick load in an intrdfoduced population of Siberian chipmunks Tamias sibiricus. Journal of Animal Ecology, 79: 538-547.

Brown, C. and Laland, K.N. 2003. Social learning in fishes: a review. Fish and Fisheries, 4: 280-288.

Brown, C., Laland, K.N. and Krause, J. 2011. Fish Cognition and Behavior, Wiley-Blackwell, Oxford.

Bshary, R. and Brown, C. 2014. Fish Cognition. Current Biology, 24: R947-R950.

Buchmann, K. 2007. Introduction to Fish Parasitological Methods: Classical and Molecular Techniques Biofolia Press, Copenhagen, Denmark.

Candolin, U. and Voigt, H.R. 2001. No effect of a parasite on reproduction in stickleback males: a laboratory artefact? Parasitology, 122: 457-464.

Careau, V., Thomas, D., Humphries, M.M. and Réale, D. 2008. Energy metabolism and animal personality. Oikos, 117: 641-653.

Chivers, D.P., Wisenden, B.D., Hindman, C.J., Michalak, T.A., Kusch, R.C., Kaminskyj, S.G.W., Jack, K.L., Ferrari, M.C.O., Pollock, R.J. and Halbgewachs, C.F. 2007. Epidermal "alarm substance” cells of fishes maintained by non-alarm functions: possible defence against pathogens, parasites and UVB radiation. Proceedings of the Royal Society of London B: Biological Sciences, 274: 2611-2619.

Conrad, J.L., Weinersmith, K.L., Brodin, T., Saltz, J.B. and Sih, A. 2011. Behavioural syndromes in fishes: a review with implications for ecology and fisheries management. Journal of Fish Biology, 78: 395-435.

Coppens, C.M., de Boer, S.F. and Koolhaas, J.M. 2010. Coping styles and behavioural flexibility: towards underlying mechanisms. Philosophical Transactions of the Royal Society B-Biological Sciences, 365: 4021-4028.

Cortés, R., Teles, M., Trídico, R., Acerete, L. and Tort, L. 2013. Effects of cortisol administered through slow-release implants on innate immune responses in rainbow trout (Oncorhynchus mykiss). International Journal of Genomics, 2013: 619714.

Côté, I.M., Arnal, C. and Reynolds, J.D. 1998. Variation in posing behaviour among fish species visiting cleaning stations. Journal of Fish Biology, 53: 256-266.

Côté, I.M. and Gross, M.R. 1993. Reduced disease in offspring: a benefit of coloniality in sunfish. Behavioral Ecology and Sociobiology, 33: 269-274.

Côté, I.M. and Poulin, R. 1995. Parasitism and group size in social animals: a meta-analysis. Behavioral Ecology, 6: 159-165.

Cote, J., Clobert, J., Brodin, T., Fogarty, S. and Sih, A. 2010. Personality-dependent dispersal: characterization, ontogeny and consequences for spatially structured populations. 

Philosophical Transactions of the Royal Society B: Biological Sciences, 365: 40654076.

Crowden, A.E. and Broom, D.M. 1980. Effects of the eyefluke, Diplostomum spathaceum, on the behavior of dace (Leuciscus leuciscus). Animal Behaviour, 28: 287-294.

Daly, E.W. and Johnson, P.T.J. 2011. Beyond immunity: quantifying the effects of host antiparasite behaviour on parasite transmission. Oecologia, 165: 1043-1050.

Demas, G.E., Adamo, S.A. and French, S.S. 2011. Neuroendocrine-immune crosstalk in vertebrates and invertebrates: implications for host defence. Functional Ecology, 25: 29-39.

DePasquale, C., Wagner, T., Archard, G.A., Ferguson, B. and Braithwaite, V.A. 2014. Learning rate and temperament in a high predation risk environment. Oecologia, 176: 661-667.

Dezfuli, B.S., Capuano, S., Simoni, E., Giari, L. and Shinn, A.P. 2007. Histopathological and ultrastructural observations of metacercarial infections of Diplostomum phoxini (Digenea) in the brain of minnows Phoxinus phoxinus. Diseases of Aquatic Organisms, 75: 51-59.

Dezfuli, B.S., Giari, L. and Shinn, A.P. 2007. The role of rodlet cells in the inflammatory response in Phoxinus phoxinus brains infected with Diplostomum. Fish \& Shellfish Immunology, 23: 300-304.

Dingemanse, N.J., Wright, J., Kazem, A.J.N., Thomas, D.K., Hickling, R. and Dawnay, N. 2007. Behavioural syndromes differ predictably between 12 populations of stickleback. Journal of Animal Ecology, 76: 1128-1138.

Dizney, L. and Dearing, M.D. 2013. The role of behavioural heterogeneity on infection patterns: implications for pathogen transmission. Animal Behaviour, 86: 911-916.

Dizney, L. and Dearing, M.D. 2016. Behavioural differences: a link between biodiversity and pathogen transmission. Animal Behaviour, 111: 341-347.

Dufour, S., Sebert, M.-E., Weltzien, F.-A., Rousseau, K. and Pasqualini, C. 2010. Neuroendocrine control by dopamine of teleost reproduction. Journal of Fish Biology, 76: 129-160.

Dukas, R. 1999. Cost of memory: ideas and predictions. Journal of Theoretical Biology, 197: 41-50.

Dukas, R. and Bernays, E.A. 2000. Learning improves growth rate in grasshoppers. Proceedings of the National Academy of Sciences of the USA, 97: 2637-2640. Ellis, T., Sanders, M.B. and Scott, A.P. 2013. Non-invasive monitoring of steroids in fishes. Wiener Tierärztliche Monatsschrift - Veterinary Medicine Austria, 100: 255-269. 
1002

1003

1004

1005

1006

1007

1008

1009

1010

1011

1012

1013

1014

1015

1016

1017

1018

1019

1020

1021

1022

1023

1024

1025

1026

1027

1028

1029

1030

1031

1032

1033

1034

1035

1036

1037

Ezenwa, V., Price, S.A., Altizer, S., Vitone, N.D. and Cook, C. 2006. Host traits and parasite species richness in even- and odd-toed hoofed mammals, Artiodactyla and Perissodactyla. Oikos, 115: 526-537.

Fincher, C.L. and Thornhill, R. 2014. The Parasite-Stress Theory of Values and Sociality: Infectious Disease, History and Human Values Worldwide. Springer Science \& Business Media, New York, 449 pp.

Fitzpatrick, J.L., Montgomerie, R., Desjardins, J.K., Stiver, K.A., Kolm, N. and Balshine, S. 2009. Female promiscuity promotes the evolution of faster sperm in cichlid fishes. Proceedings of the National Academy of Sciences of the USA, 106: 1128-1132.

Fredensborg, B.L. and Longoria, A.N. 2012. Increased surfacing behavior in longnose killifish infected by brain-encysting trematode. Journal of Parasitology, 98: 899-903.

Giles, N. 1983. Behavioral effects of the parasite Schistocephalus solidus (Cestoda) on an intermediate host, the three-spined stickleback, Gasterosteus aculeatus L. Animal Behaviour, 31: 1192-1194.

Goater, C.P., Bray, D. and Conn, D.B. 2005. Cellular aspects of early development of Ornithodiplostomum ptychocheilus metacercariae in the brain of fathead minnows, Pimephales promelas. Journal of Parasitology, 91: 814-821.

Godin, J.-G.J. 1999. Behavioural Ecology of Teleost Fishes. OUP, Oxford.

Gopko, M., Mikheev, V.N. and Taskinen, J. 2015. Changes in host behaviour caused by immature larvae of the eye fluke: evidence supporting the predation suppression hypothesis. Behavioral Ecology and Sociobiology, 69: 1723-1730.

Griffin, A.S., Guillette, L.M. and Healy, S.D. 2015. Cognition and personality: an analysis of an emerging field. Trends in Ecology \& Evolution, 30: 207-214.

Haas, N., Wulff, C., Grabe, K., Meyer, V. and Haeberlein, S. 2007. Navigation within host tissues: cues for orientation of Diplostomum spathaceum (Trematoda) in fish towards veins, head and eye. Parasitology, 134: 1013-1023.

Hafer, N. and Milinski, M. 2016. An experimental conflict of interest between parasites reveals the mechanism of host manipulation. Behavioral Ecology, 27: 617-627.

Hammond-Tooke, C.A., Nakagawa, S. and Poulin, R. 2012. Parasitism and behavioural syndromes in the fish Gobiomorphus cotidianus. Behaviour, 149: 601-622.

Hart, B.L. 1990. Behavioral adaptations to pathogens and parasites - 5 strategies. Neuroscience \& Biobehavioral Reviews, 14: 273-294.

— 1997. Behavoural defence. In: D.H. Clayton and J. Moore (Editors), Host-parasite evolution: general principle and avian models, Oxford University Press, Oxford, UK.

Hawley, D.M., Etienne, R.S., Ezenwa, V.O. and Jolles, A.E. 2011. Does animal behavior underlie covariation between hosts' exposure to infectious agents and susceptibility to 

infection? Implications for disease dynamics. Integrative and Comparative Biology, 51: 528-539.

Hébert, F.O. and Aubin-Horth, N. 2014. Ecological genomics of host behavior manipulation by parasites. In: C. Landry and N. Aubin-Horth (Editors), Ecological Genomics, Springer Netherlands.

Hébert, F.O., Grambauer, S., Barber, I., Landry, C.R. and Aubin-Horth, N. 2016. Transcriptome sequences spanning key developmental states as a resource for the study of the cestode Schistocephalus solidus, a threespine stickleback parasite. GigaScience, 5: 24.

Hébert, F.O., Grambauer, S., Barber, I., Landry, C.R. and Aubin-Horth, N. submitted. Major host transitions are modulated through transcriptome-wide reprograming events in the cestode Schistocephalus solidus, a threespine stickleback parasite. Molecular Ecology.

Hébert, F.O., Phelps, L., Samonte, I., Panchal, M., Grambauer, S., Barber, I., Kalbe, M., Landry, C.R. and Aubin-Horth, N. 2015. Identification of candidate mimicry proteins involved in parasite-driven phenotypic changes. Parasites \& Vectors, 8: 225.

Heins, D.C. and Baker, J.A. 2008. The stickleback-Schistocephalus host-parasite system as a model for understanding the effect of a macroparasite on host reproduction. Behaviour, 145: 625-645.

Heins, D.C., Baker, J.A. and Martin, H.C. 2002. The "crowding effect" in the cestode Schistocephalus solidus: density-dependent effects on plerocercoid size and infectivity. Journal of Parasitology, 88: 302-207.

Hendrickson, G.L. 1979. Ornithodiplostomum ptychocheilus: Migration to the brain of the fish intermediate host, Pimephales promelas. Experimental Parasitology, 48: 245258.

Hughes, D.P. 2013. Pathways to understanding the extended phenotype of parasites in their hosts. Journal of Experimental Biology, 216: 142-147.

Huntingford, F.A. and Ruiz-Gomez, M.L. 2009. Three-spined sticklebacks Gasterosteus aculeatus as a model for exploring behavioural biology. Journal of Fish Biology, 75: 1943-1976.

Ims, R.A. 1990. On the adaptive value of reproductive synchrony as a predator-swamping strategy. American Naturalist, 136: 485-498.

Jacquin, L., Reader, S.M., Boniface, A., Mateluna, J., Patalas, I., Perez-Jvostov, F. and Hendry, A.P. 2016. Parallel and nonparallel behavioural evolution in response to parasitism and predation in Trinidadian guppies. Journal of Evolutionary Biology, 29: 1406-1422 
James, C.T., Noyes, K.J., Stumbo, A.D., Wisenden, B.D. and Goater, C.P. 2008. Cost of exposure to trematode cercariae and learned recognition of avoidance and parasitism risk by fathead minnows Pimephales promelas. Journal of Fish Biology, 73: 22382248.

Jolles, J.W., Manica, A. and Boogert, N.J. 2016. Food intake rates of inactive fish are positively linked to boldness in three-spined sticklebacks Gasterosteus aculeatus. Journal of Fish Biology, 88: 1661-1668.

Karvonen, A., Seppälä, O. and Valtonen, E.T. 2004. Parasite resistance and avoidance behaviour in preventing eye fluke infections in fish. Parasitology, 129: 159-164.

Kekäläinen, J., Lai, Y.T., Vainikka, A., Sirkka, I. and Kortet, R. 2014. Do brain parasites alter host personality? - Experimental study in minnows. Behavioural Ecology and Sociobiology, 68: 197-204.

Kern, E.M.A., Robinson, D., Gass, E., Godwin, J. and Langerhans, R.B. 2016. Correlated evolution of personality, morphology and performance. Animal Behaviour, 117: 7986.

Kittilsen, S., Johansen, I.B., Braastad, B.O. and Øverli, Ø. 2012. Pigments, parasites and personalitiy: towards a unifying role for steroid hormones? Plos One, 7.

Kittilsen, S., Schjolden, J., Johansen, I.B., Shaw, J.C., Pottinger, T.G., Sørensen, C., Braastad, B.O., Bakken, M. and Øverli, Ø. 2009. Melanin-based skin spots reflect stress responsiveness in salmonid fish. Hormones and Behavior, 56: 292-298.

Klemme, I. and Karvonen, A. 2016. Learned parasite avoidance is driven by host personality and resistance to infection in a fish-trematode interaction. Proceedings of the Royal Society B-Biological Sciences, 283: 20161148.

Klemme, I., Kortet, R. and Karvonen, A. 2016. Parasite infection in a central sensory organ of fish does not affect host personality. Behavioral Ecology, 27: 1533-1538.

Koolhaas, J.M. 2008. Coping style and immunity in animals: making sense of individual variation. Brain, Behaviour and Immunity, 22: 662-667.

Koprivnikar, J., Gibson, C.H. and Redfern, J.C. 2012. Infectious personalities: behavioural syndromes and disease risk in larval amphibians. Proceedings of the Royal Society BBiological Sciences, 279: 1544-1550.

Kortet, R., Hedrick, A.V. and Vainikka, A. 2010. Parasitism, predation and the evolution of animal personalities. Ecology Letters, 13: 1449-1458.

Kortet, R., Sirkka, I., Lai, Y.-T., Vainikka, A. and Kekäläinen, J. 2015. Personality differences in two minnow populations that differ in their parasitism and predation risk. Frontiers in Ecology and Evolution, 3: 9. 
Kotrschal, A., Corral-Lopez, A., Amcoff, M. and Kolm, N. 2014. A larger brain confers a benefit in a spatial mate search learning task in male guppies. Behavioral Ecology, 26: 527-532.

Lafferty, K.D. and Morris, A.K. 1996. Altered behavior of parasitized killifish increases susceptibility to predation by bird final hosts. Ecology, 77: 1390-1397.

Lester, R.J.G. 1971. Influence of Schistocephalus plerocercoids on respiration of Gasterosteus and a possible resulting effect on behavior of fish. Canadian Journal of Zoology, 49: 361-366.

Lindström, K. and Lehtonen, T.K. 2013. Mate sampling and choosiness in the sand goby. Proceedings of the Royal Society B-Biological Sciences, 280: 20130983.

Lobue, C.P. and Bell, M.A. 1993. Phenotypic manipulation by the cestode parasite Schistocephalus solidus of Its intermediate host, Gasterosteus aculeatus, the threespine stickleback. American Naturalist, 142: 725-735.

Loot, G., Brosse, S., Lek, S. and Guegan, J.F. 2001. Behaviour of roach (Rutilus rutilus L.) altered by Ligula intestinalis (Cestoda : Pseudophyllidea): a field demonstration. Freshwater Biology, 46: 1219-1227.

Macnab, V. and Barber, I. 2012. Some (worms) like it hot: fish parasites grow faster in warmer water, and alter host thermal preferences. Global Change Biology, 18: 15401548.

Macnab, V., Katsiadaki, I. and Barber, I. 2009. Reproductive potential of Schistocephalus solidus-infected male three-spined stickleback Gasterosteus aculeatus from two UK populations. Journal of Fish Biology, 75: 2095-2107.

Macnab, V., Scott, A.P., Katsiadaki, I. and Barber, I. 2011. Variation in the reproductive potential of Schistocephalus infected male sticklebacks is associated with 11ketotestosterone titre. Hormones and Behavior, 60: 371-379.

Magnhagen, C., Braithwaite, V.A., Forsgren, E. and Kapoor, B.G. 2008. Fish Behaviour. CRC Press, Boca Raton, FL, 662 pp.

Mamuneas, D., Spence, A.J., Manica, A. and King, A.J. 2015. Bolder stickleback fish make faster decisions, but they are not less accurate. Behavioral Ecology, 26: 91-96.

Martins, E.P. and Bhat, A. 2014. Population-level personalities in zebrafish: aggressionboldness across but not within populations. Behavioral Ecology, 25: 368-373.

Matisz, C.E. and Goater, C.P. 2010. Migration, site selection, and development of Ornithodiplostomum sp. metacercariae (Digenea: Strigeoidea) in fathead minnows (Pimephales promelas). International Journal for Parasitology, 40: 1489-1496.

Matisz, C.E., Goater, C.P. and Bray, D. 2010. Migration and site selection of Ornithodiplostomum ptychocheilus (Trematoda: Digenea) metacercariae in the brain of fathead minnows (Pimephaies promelas). Parasitology, 137: 719-731. 
McCusker, R.H. and Kelley, K.W. 2013. Immune-neural connections: how the immune system's response to infectious agents influences behavior. Journal of Experimental Biology, 216: 84-98.

Meakins, R.H. and Walkey, M. 1975. Effects of parasitism by plerocercoid of Schistocephalus solidus Müller 1776 (Pseudophyllidea) on respiration of three-spined stickleback Gasterosteus aculeatus L. Journal of Fish Biology, 7: 817-824.

Mikheev, V.N., Pasternak, A.F., Taskinen, J. and Valtonen, E.T. 2010. Parasite-induced aggression and impaired contest ability in a fish host. Parasites \& Vectors, 3: 17.

Mikheev, V.N., Pasternak, A.F., Taskinen, J. and Valtonen, T.E. 2013. Grouping facilitates avoidance of parasites by fish. Parasites \& Vectors, 6: 301.

Mikheev, V.N., Pasternak, A.F. and Valtonen, E.T. 2004. Tuning host specificity during the ontogeny of a fish ectoparasite: behavioural responses to host induced cues. Parasitology Research, 92: 220-224.

Mikheev, V.N., Pasternak, A.F., Valtonen, E.T. and Taskinen, J. 2014. Increased ventilation by fish leads to a higher risk of parasitism. Parasites \& Vectors, 7: 281.

Milinski, M. 1984. Parasites determine a predators optimal feeding strategy. Behavioral Ecology and Sociobiology, 15: 35-37.

—. 1985. Risk of predation of parasitized sticklebacks (Gasterosteus aculeatus L) under competition for food. Behaviour, 93: 203-215.

_ 1990. Parasites and host decision-making. In: C.J. Barnard and J.M. Behnke (Editors), Parasitism and host behaviour, Taylor and Francis, London.

Mohammed, R.S., Reynolds, M., James, J., Williams, C., Mohammed, A., Ramsubhag, A., van Oosterhout, C. and Cable, J. 2016. Getting into hot water: sick guppies frequent warmer thermal conditions. Oecologia, 181: 911-917.

Moore, J. 2002. Parasites and the Behavior of Animals. Oxford University Press, Oxford, UK, 315 pp.

— 2012. A history of parasites and hosts, science and fashion. In: D. Hughes, J. Brodeur and F. Thomas (Editors), Host Manipulation By Parasites, Oxford University Press, Oxford.

_ 2013. An overview of parasite-induced behavioral alterations-and some lessons from bats. Journal of Experimental Biology, 216: 11-17.

Mooring, M.S. and Hart, B.L. 1992. Animal grouping for protection from parasites: selfish herd and encounter-dilution effects. Behaviour, 123: 173-193.

Niemelä, P., Vainikka, A., Forsman, J.T., Loukola, O.J. and Kortet, R. 2013. How does variation in the environment and individual cognition explain the existence of consistent individual behavioral differences? Ecology and Evolution, 3: 457-464. 
Norton, W.H.J., Stumpenhorst, K., Faus-Kessler, T., Folchert, A., Rohner, N., Harris, M.P., Callebert, J. and Bally-Cuif, L. 2011. Modulation of fgfr1a signaling in zebrafish reveals a genetic basis for the aggression-boldness syndrome. The Journal of Neuroscience, 31: 13796.

Nunn, C.L., Altizer, S., Jones, K. and Sechrest, W. 2003. Comparative tests of parasites species richness in primates. American Naturalist, 162: 597-614.

Oliveira, R. 2013. Mind the fish: zebrafish as a model in cognitive social neuroscience. Frontiers in Neural Circuits, 7: 131.

Øverli, Ø., Kotzian, S. and Winberg, S. 2002. Effects of cortisol on aggression and locomotor activity in rainbow trout. Hormones and Behavior, 42: 53-61.

Øverli, Ø., Páll, M., Borg, B., Jobling, M. and Winberg, S. 2001. Effects of Schistocephalus solidus infection on brain monoaminergic activity in female three-spined sticklebacks Gasterosteus aculeatus. Proceedings of the Royal Society of London Series BBiological Sciences, 268: 1411-1415.

Øverli, Ø., Pottinger, T.G., Carrick, T.R. and Øverli, E. 2001. Brain monoaminergic activity in rainbow trout selelction for high and low stress responsiveness. Brain, Behavior and Evolution, 57: 214-224.

Øverli, Ø., Pottinger, T.G., Carrick, T.R., Øverli, E. and Winberg, S. 2002. Differences in behaviour between rainbow trout selected for high- and low-stress responsiveness. Journal of Experimental Biology, 205: 391-395.

Øverli, Ø., Winberg, S. and Pottinger, T.G. 2005. Behavioral and neuroendocrine correlates of selection for stress responsiveness in rainbow trout-a review. Integrative and Comparative Biology, 45: 463-474.

Owen, S.F., Barber, I. and Hart, P.J.B. 1993. Low-level infection by eye fluke, Diplostomum spp, affects the vision of three-spined sticklebacks, Gasterosteus aculeatus. Journal of Fish Biology, 42: 803-806.

Patterson, J.E.H. and Ruckstuhl, K.E. 2013. Parasite infection and host group size: a metaanalytical review. Parasitology, 140: 803-813.

Pélabon, C., Borg, A.A., Bjelvenmark, J., Barber, I., Forsgren, E. and Amundsen, T. 2005. Do microsporidian parasites affect courtship in two-spotted gobies? Marine Biology, 148: 189-196.

Petney, T.N. and Andrews, R.H. 1998. Multiparasite communities in animals and humans: frequency, structure and pathogenic significance. International Journal for Parasitology, 28: 377-393.

Pitcher, T.J. 1993. Behaviour of Teleost Fishes. Chapman \& Hall, London.

Pitcher, T.J. and Parrish, J.K. 1993. Functions of shoaling behaviour in teleosts. In: T.J. Pitcher (Editor), Behaviour of Teleost Fishes, Chapman \& Hall, London. 
Poulin, R. 1994. The evolution of parasite manipulation of host behavior - a theoretical analysis. Parasitology, 109: S109-S118.

Poulin, R. 2010. Parasite manipulation of host behavior: an update and frequently asked questions. Advances in the Study of Behavior, 41: 151-186.

Poulin, R. 2013. Parasite manipulation of host personality and behavioural syndromes. Journal of Experimental Biology, 216: 18-26.

Poulin, R. and Fitzgerald, G.J. 1989. Risk of parasitism and microhabitat selection in juvenile sticklebacks. Canadian Journal of Zoology-Revue Canadienne De Zoologie, 67: 1418.

Poulin, R. and Morand, S. 1999. Geographical distances and the similarity among parasite communities of conspecific host populations. Parasitology, 119: 369-374.

Quinn, T.P., Kendall, N.W., Rich, H.B., Jr. and Chasco, B.E. 2012. Diel vertical movements, and effects of infection by the cestode Schistocephalus solidus on daytime proximity of three-spined sticklebacks Gasterosteus aculeatus to the surface of a large Alaskan lake. Oecologia, 168: 43-51.

Reale, D., Garant, D., Humphries, M.M., Bergeron, P., Careau, V. and Montiglio, P.O. 2010. Personality and the emergence of the pace-of-life syndrome concept at the population level. Philosophical Transactions of the Royal Society B-Biological Sciences, 365: 4051-4063.

Reale, D., Reader, S.M., Sol, D., McDougall, P.T. and Dingemanse, N.J. 2007. Integrating animal temperament within ecology and evolution. Biological Reviews of the Cambridge Philosophical Society, 82: 291-318.

Reebs, S. 2001. Fish Behavior in the Aquarium and in the Wild. Cornell University Press, Ithaca, USA.

Richards, E.L. 2010. Foraging, personality and parasites: investigations into the behavioural ecology of fishes, Cardiff University, Cardiff.

Richards, E.L., van Oosterhout, C. and Cable, J. 2010. Sex-specific differences in shoaling affect parasite transmission in guppies. PLoS ONE, 5: e13285. 2012. Interactions between males guppies facilitates the transmission of the monogenean ectoparasite Gyrodactylus turnbulli. Experimental Parasitology: 483486.

Rifkin, J.L., Nunn, C. and Garamszegi, L. 2012. Do animals living in larger groups experience greater parasitism? A meta-analysis. American Naturalist, 180: 70-82.

Roberts, K.E., Evison, S.E.F., Baer, B. and Hughes, W.O.H. 2015. The cost of promiscuity: sexual transmission of Nosema microsporidian parasites in polyandrous honey bees. Scientific Reports, 5: 10982. 
Rynkiewicz, E.C., Pedersen, A.B. and Fenton, A. 2015. An ecosystem approach to understanding and managing within-host parasite community dynamics. Trends in Parasitology, 31: 212-221.

Sandland, G.J. and Goater, C.P. 2000. Development and intensity dependence of Ornithodiplostomum ptychocheilus metacercariae in fathead minnows (Pimephales promelas). Journal of Parasitology, 86: 1056-1060.

Sasal, P. 2003. Experimental test of the influence of the size of shoals and density of fish on parasite infections. Coral Reefs, 22: 241-246.

Scott, A.P., Hirschenhauser, K., Bender, N., Oliveira, R., Earley, R.L., Sebire, M., Ellis, T., Pavlidis, M., Hubbard, P.C. and Huertas, M. 2008. Non-invasive measurement of steroids in fish-holding water: important considerations when applying the procedure to behaviour studies. Behaviour, 145: 1307-1328.

Scott, M.E. 1985. Dynamics of challenge infections of Gyrodactylus bullatarudis Turnbull (Monogenea) on guppies, Poecilia reticulata (Peters). Journal of Fish Diseases, 8: 495-503.

Seppälä, O., Karvonen, A. and Valtonen, E.T. 2005. Manipulation of fish host by eye flukes in relation to cataract formation and parasite infectivity. Animal Behaviour, 70: 889894.

ـ 2006. Susceptibility of eye fluke-infected fish to predation by bird hosts. Parasitology, 132: 575-579.

Seppälä , O., Karvonen, A. and Valtonen, E.T. 2008. Shoaling behaviour of fish under parasitism and predation risk. Animal Behaviour, 75: 145-150.

Seppälä, O., Karvonen, A. and Valtonen, E.T. 2011. Eye fluke-induced cataracts in natural fish populations: is there potential for host manipulation? Parasitology, 138: 209-214.

Seppälä, O., Karvonen, A., Valtonen, E.T. and Jokela, J. 2009. Interactions among coinfecting parasite species: a mechanism maintaining genetic variation in parasites? Proceedings of the Royal Society B-Biological Sciences, 276: 691-697.

Shaw, J.C., Hechinger, R.F., Lafferty, K.D. and Kuris, A.M. 2010. Ecology of the brain trematode Euhaplorchis californiensis and its host, the California killifish (Fundulus parvipinnis). Journal of Parasitology, 96: 482-490.

Shaw, J.C., Korzan, W.J., Carpenter, R.E., Kuris, A.M., Lafferty, K.D., Summers, C.H. and Øverli, Ø. 2009. Parasite manipulation of brain monoamines in California killifish (Fundulus parvipinnis) by the trematode Euhaplorchis californiensis. Proceedings of the Royal Society B-Biological Sciences, 276: 1137-1146.

Shaw, J.C. and Øverli, Ø. 2012. Brain-encysting trematodes and altered monoamine activity in naturally infected killifish Fundulus parvipinnis. Journal of Fish Biology, 81: 2213-2222. 
Shettleworth, S.J. 2010. Cognition, Evolution and Behaviour. Oxford University Press, Oxford.

Shirakashi, S. and Goater, C.P. 2002. Intensity-dependent alteration of minnows (Promephales promelas) behavior by a brain-encysting trematode. Journal of Parasitology, 88: 1071-1074.

— 2005. Chronology of parasite-induced alteration of fish behaviour: effects of parasite maturation and host experience. Parasitology, 130: 177-183.

Sih, A. 1992. Prey uncertainty and the balancing of antipredator and feeding needs. American Naturalist, 139: 1052-1069.

Sih, A. and Bell, A.M. 2008. Insights for behavioral ecology from behavioral syndromes. Advances in the Study of Behavior, 38: 227-281.

Sih, A., Bell, A.M. and Johnson, J.C. 2004. Behavioral syndromes: an ecological and evolutionary overview. Trends in Ecology \& Evolution, 19: 372-378.

Sih, A. and del Giudice, M. 2012. Linking behavioural syndromes and cognition: a behavioural ecology perspective. Philosophical Transactions of the Royal Society BBiological Sciences, 367: 2762-2772.

Smyth, J.D. 1990. In vitro cultivation of parasitic helminths CRC Press, Boca Raton, FL, 276 pp.

Spagnoli, S., Sanders, J. and Kent, M.L. 2016. The common neural parasite Pseudoloma neurophilia causes altered shoaling behaviour in adult laboratory zebrafish (Danio rerio) and its implications for neurobehavioural research. Journal of Fish Diseases.

Spagnoli, S., Xue, L. and Kent, M.L. 2015. The common neural parasite Pseudoloma neurophilia is associated with altered startle response habituation in adult zebrafish (Danio rerio): Implications for the zebrafish as a model organism. Behavioural Brain Research, 291: 351-360.

Spence, R., Magurran, A.E. and Smith, C. 2011. Spatial cognition in zebrafish: the role of strain and rearing environment. Animal Cognition, 14: 607-612.

Sternberg, R.J., Powell, C., McGrane, P. and Grantham-McGregor, S. 1997. Effects of a parasitic infection on cognitive functioning. Journal of Experimental Psychology, 3: 67-76.

Stumbo, A.D., James, C.T., Goater, C.P., Wisenden, B.D. and Cotter, S. 2012. Shoaling as an antiparasite defence in minnows (Pimephales promelas) exposed to trematode cercariae. Journal of Animal Ecology, 81: 1319-1326.

Stumbo, A.D. and Poulin, R. 2016. Possible mechanism of host manipulation resulting from a diel behaviour pattern of eye-dwelling parasites? Parasitology, 143: 1261-1267.

Sukhdeo, M.V.K. 1994. Parasites and Behaviour. Parasitology, 109 (Supplement): S1-S148. 
Thomas, F., Adamo, S. and Moore, J. 2005. Parasitic manipulation: where are we and where should we go? Behavioural Processes, 68: 185-199.

Tierney, J.F. and Crompton, D.W.T. 1992. Infectivity of plerocercoids of Schistocephalus solidus (Cestoda, Ligulidae) and fecundity of the adults in an experimental definitive host, Gallus gallus. Journal of Parasitology, 78: 1049-1054.

Tierney, J.F., Huntingford, F.A. and Crompton, D.W.T. 1993. The relationship between infectivity of Schistocephalus solidus (Cestoda) and antipredator behavior of its intermediate host, the three-spined stickleback, Gasterosteus aculeatus. Animal Behaviour, 46: 603-605.

Toms, C.N., Echevarria, D.J. and Jouandot, D.J. 2010. A methodological review of personality-related studies in fish: focus on the shy-bold axis of behavior. International Journal of Comparative Psychology, 23: 1-25.

Trompf, L. and Brown, C. 2014. Personality affects learning and trade-offs between private and social information in guppies, Poecilia reticulata. Animal Behaviour, 88: 99106.

Turnbull, J.F., Adams, C.E., Richards, R.H. and Robertson, D.A. 1998. Attack site and resultant damage during aggressive encounters in Atlantic salmon. Aquaculture, 159: 345-353.

White, S.J., Kells, T.J. and Wilson, A.J. 2016. Metabolism, personality and pace of life in the Trinidadian guppy, Poecilia reticulata. Behaviour, in press.

Wilson, A.D.M., Krause, J., Herbert-Read, J.E. and Ward, A.J.W. 2014. The personality behind cheating: behavioural types and the feeding ecology of cleaner fish. Ethology, 120: 904-912.

Wilson, D.S. 1998. Adaptive individual differences within single populations. Philosophical Transactions of the Royal Society B-Biological Sciences, 353: 199-205.

Wilson, D.S., Coleman, K., Clark, A.B. and Biederman, L. 1993. Shy-bold continuum in pumpkinseed sunfish (Lepomis gibbosus) - an ecological study of a psychological trait. Journal of Comparative Psychology, 107: 250-260.

Winberg, S., Nilsson, A., Hylland, P., Söderstöm, V. and Nilsson, G.E. 1997. Serotonin as a regulatory of hypothalamic-pituitary-interrenal activity in teleost fish. Neuroscience Letters, 230: 113-116.

Winberg, S. and Nilsson, G.E. 1993. Roles of brain monoamine neurotransmitters in agonistic behavior and stress reactions, with particular reference to fish. Comparative Biochemistry and Physiology C - Pharmacology Toxicology and Endocrinology, 106: 597-614.

Wisenden, B.D., Goater, C.P. and James, C.T. 2009. Behavioral defenses against parasites and pathogens. In: G. Zaccone, C. Perrière, A. Mathis and B.G. Kapoor (Editors), 
1365

1366

1367

1368

1369

1370

1371

1372

1373

1374

1375

1376

1377

1378

1379

1380

Fish Defenses. Volume 2: Pathogens, Parasites, and Predators, Science Publishers, Enfield, New Hampshire.

Wisenden, B.D., Martinez-Marquez, J.Y., Gracia, E.S. and McEwen, D.C. 2012. High intensity and prevalence of two species of metacercariae in the fathead minnow (Pimephales promelas) with no compromise of minnow anti-predator competence. Journal of Parasitology, 98: 722-727.

Woo, P.T.K. and Buchmann, K. 2011. Fish Parasites: Pathobiology and Protection. CABI, London, 360 pp.

Wootton, R.J. 1976. The biology of the sticklebacks Academic Press, London 387 pp.

Zylberberg, M., Klasing, K. and Hahn, T. 2013. House finches (Carpodacus mexicanus) balance investment in behavioral and immunological defenses against pathogens. Biology Letters, 53: E400.

Zylberberg, M., Klasing, K.C. and Hahn, T.P. 2014. In house finches, Haemorhous mexicanus, risk takers invest more in innate immune function. Animal Behaviour, 89: 115-122. 